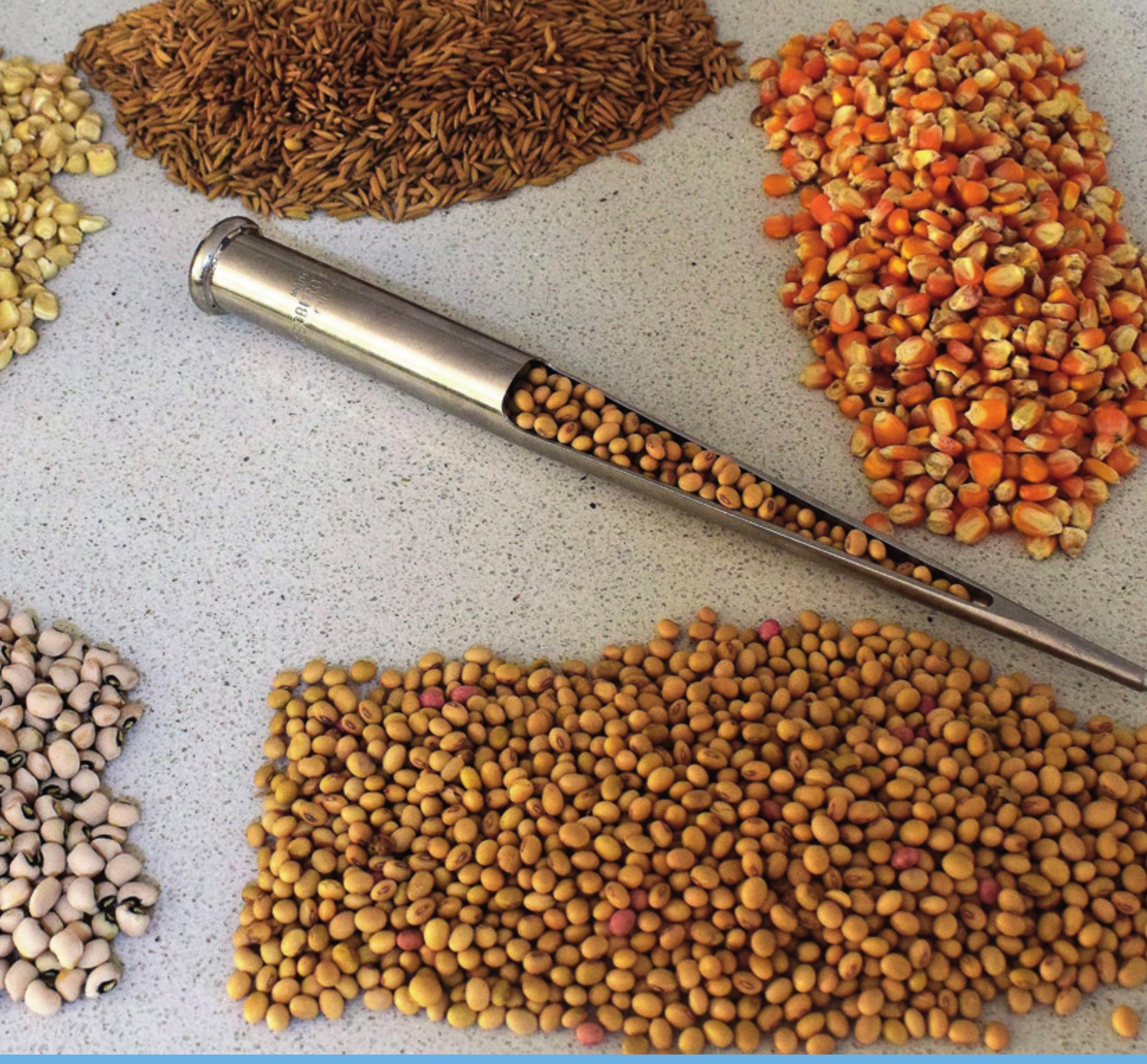

National Seed Road Map for Nigeria

Document submitted to the Netherlands Enterprise Agency (RVO) and Embassy of the Kingdom of the Netherlands, Abuja, in conclusion of a seed sector review in Nigeria (September 2019 - February 2020) 



\section{National Seed Road Map for Nigeria}

Document submitted to the Netherlands Enterprise Agency (RVO) and Embassy of the Kingdom of the Netherlands, Abuja, in conclusion of a seed sector review in Nigeria (September 2019 - February 2020) 
NASC \& SEEDAN, 2020. National Seed Road Map for Nigeria; Document submitted to the Netherlands Enterprise Agency (RVO) and Embassy of the Kingdom of the Netherlands, Abuja, in conclusion of a seed sector review in Nigeria (September 2019 - February 2020). National Agricultural Seeds Council, Abuja, Federal Capital Territory; and Seed Entrepreneurs Association of Nigeria, Abuja, Federal Capital Territory. Wageningen Centre for Development Innovation, Wageningen University \& Research. Report WCDI-20-099. Wageningen.

The seed sector review of which the National Seed Road Map is an outcome was a joint activity shaping the collaboration between the Federal Ministry of Agriculture and Rural Development of Nigeria and the Embassy of the Kingdom of the Netherlands, Abuja

\section{1) FMARD}

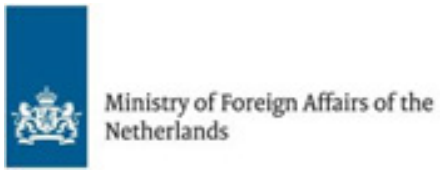

The National Seed Road Map is the result of a consultative process in which critical stakeholders of the seed sector in Nigeria participated. The policy context for this process is an agreement between the Federal Ministry of Agriculture and Rural Development (FMARD) of the Government of Nigeria and the Embassy of the Kingdom of the Netherlands (EKN) in Abuja to jointly engage in a seed sector review, exploring ways to collaborate in the development of Nigeria's seed sector. One of the steps in this review was the development of a multi-year seed sector development strategy or National Seed Road Map. A team of consultants has been contracted by the EKN through the Netherlands Enterprise Agency (RVO). The team included members of Wageningen Centre for Development Innovation (WCDI), Sahel Consulting, National Agricultural Seeds Council (NASC), East-West Seed (Company and Knowledge Transfer Foundation) and EKN.

The seed sector review was financed by:

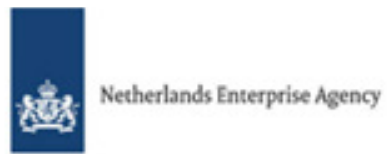

This report can be downloaded for free at https://doi.org/10.18174/517834 or at www.wur.eu/cdi (under publications).

C 2020 Wageningen Centre for Development Innovation, part of the Stichting Wageningen Research. P.O. Box 88, 6700 AB Wageningen, The Netherlands. T + 31 (0)317 4868 00, E info.cdi@wur.nl, www.wur.eu/cdi.

\section{(cc) BY-NC}

The Wageningen Centre for Development Innovation uses a Creative Commons Attribution 4.0 (Netherlands) licence for its reports.

The user may copy, distribute and transmit the work and create derivative works. Third-party material that has been used in the work and to which intellectual property rights apply may not be used without prior permission of the third party concerned. The user must specify the name as stated by the author or licence holder of the work, but not in such a way as to give the impression that the work of the user or the way in which the work has been used are being endorsed. The user may not use this work for commercial purposes.

The Wageningen Centre for Development Innovation accepts no liability for any damage arising from the use of the results of this research or the application of the recommendations.

\section{Report WCDI-20-099}

Photo cover: Picture courtesy of NASC. 


\section{Contents}

List of abbreviations and acronyms

1.1 Purpose

1.2 Guiding seed sector transformation

$2.1 \quad$ Agricultural development

2.2 Policy context

2.3 Seed sector stakeholders

$\begin{array}{lll}2.4 & \text { Farmers' current seed sources } & 21\end{array}$

2.5 The seed gap

2.6 Seed sector challenges

3 Where do we want to go?

$4.1 \quad$ Strategic innovation pathways $\quad 29$

4.2 Development partners and SIPs $\quad 30$

$\begin{array}{lll}4.3 & \text { Service provision } & 31\end{array}$

4.4 Production systems 33

$\begin{array}{lll}4.5 & \text { Market development } & 37\end{array}$

$\begin{array}{lll}4.6 & \text { Revenue generation \& reinvestment } & 43\end{array}$

$\begin{array}{lll}4.7 & \text { Coordination \& governance } & 45\end{array}$

$\begin{array}{lll}4.8 & \text { Regulation \& management } & 49\end{array}$

$\begin{array}{lr}\text { References and links } & 53\end{array}$ 



\section{List of abbreviations and acronyms}

\begin{tabular}{|c|c|}
\hline ADWG & Agricultural Development Working Group \\
\hline APP & Agricultural Promotion Policy \\
\hline BASICS & $\begin{array}{l}\text { Building an Economically Sustainable Integrated Seed System for Cassava for } \\
\text { Nigeria }\end{array}$ \\
\hline B2B & Business to business \\
\hline BPAT & Breeding Program Assessment Tool \\
\hline CBSP & Community Based Seed Production \\
\hline COMESA & Common Market for Eastern and Southern Africa \\
\hline CSO & Civil society organization \\
\hline DUS & Distinctiveness, uniformity and stability \\
\hline EGS & Early generation seed \\
\hline FGD & Focus group discussion \\
\hline GES & Growth Enhancement Scheme \\
\hline $\mathrm{HV}$ & Hybrid varieties \\
\hline ICT & Information and communication technology \\
\hline IMS & Information management and sharing \\
\hline ISSD & Integrated Seed Sector Development \\
\hline NARI & National Agricultural Research Institute \\
\hline NCVLBRRC & $\begin{array}{l}\text { National Crop Varieties and Livestock Breeds Registration and Release } \\
\text { Committee }\end{array}$ \\
\hline NGO & Non-governmental organization \\
\hline NSRM & National Seed Road Map \\
\hline OPV & Open-pollinated variety \\
\hline PASS & Programme for Africa's Seeds Systems \\
\hline PPP & Public-private partnership \\
\hline PVP & Plant variety protection \\
\hline QDS & Quality declared seed \\
\hline RTB & Roots, Tubers and Bananas \\
\hline SIP & Strategic innovation pathway \\
\hline SSA & Sub-Saharan Africa \\
\hline STA & Seed Trade Association \\
\hline TRIPS & Trade-Related Aspects of Intellectual Property Rights \\
\hline VCU & Value for cultivation and use \\
\hline
\end{tabular}




\section{List of organizations}

\begin{tabular}{|c|c|}
\hline$A B U$ & Ahmadu Bello University, Zaria, Kaduna State, Nigeria \\
\hline AECF & Africa Enterprise Challenge Fund, Nairobi, Kenya \\
\hline AfDB & African Development Bank, Abidjan, Côte d'Ivoire \\
\hline AFSTA & African Seed Trade Association \\
\hline AGRA & Alliance for a Green Revolution in Africa, Nairobi, Kenya \\
\hline ASIWA & Alliance for Seed Industry in West Africa \\
\hline AtSI & Access to Seeds Index, Amsterdam, the Netherlands \\
\hline BMGF & Bill \& Melinda Gates Foundation, Seattle, USA \\
\hline BNDA & Banque Nationale du Mali, Bamako, Mali \\
\hline CARD & Coalition for African Rice Development, hosted at AGRA, Nairobi, Kenya \\
\hline CBN & Central Bank of Nigeria, Abuja, Federal Capital Territory (FCT), Nigeria \\
\hline CIP & International Potato Center (CGIAR Research Center) \\
\hline ECOWAS & Economic Community of West African States, Abuja, FCT, Nigeria \\
\hline EBA & Enabling the Business of Agriculture, World Bank, Washington-DC, USA \\
\hline EKN & Embassy of the Kingdom of the Netherlands, Abuja, FCT, Nigeria \\
\hline FAO & Food and Agriculture Organization of the United Nations \\
\hline FMARD & Federal Ministry of Agriculture and Rural Development, Abuja, FCT, Nigeria \\
\hline FMoF & Federal Ministry of Finance, Abuja, FCT, Nigeria \\
\hline $\mathrm{GiZ}$ & German Corporation for International Cooperation, Bonn/Eschborn, Germany \\
\hline GNIS & French Interprofessional Organisation for Seeds and Plants, Paris, France \\
\hline IAR & Institute for Agricultural Research, Zaria, Kaduna State, Nigeria \\
\hline ICD & $\begin{array}{l}\text { Islamic Corporation for the Development of the Private Sector, Jeddah, Saudi } \\
\text { Arabia (part of the Islamic Development Bank Group) }\end{array}$ \\
\hline ICRISAT & $\begin{array}{l}\text { International Crops Research Institute for the Semi-Arid Tropics, Hyderabad, } \\
\text { India (CGIAR Research Center) }\end{array}$ \\
\hline IFAD & International Fund for Agricultural Development, Rome, Italy \\
\hline IFC & $\begin{array}{l}\text { International Finance Corporation, Washington-DC, USA (part of World Bank } \\
\text { Group) }\end{array}$ \\
\hline IFDC & International Fertilizer Development Center, Muscle Shoals-AL, USA \\
\hline IFPRI & $\begin{array}{l}\text { International Food Policy Research Institute, Washington-DC, USA (CGIAR } \\
\text { Research Center) }\end{array}$ \\
\hline IITA & $\begin{array}{l}\text { International Institute of Tropical Agriculture, Ibadan, Oyo State, Nigeria } \\
\text { (CGIAR Research Center) }\end{array}$ \\
\hline IsDB & Islamic Development Bank, Jeddah, Saudi Arabia \\
\hline ISTA & International Seed Testing Association, Bassersdorf, Switzerland \\
\hline JICA & Japan International Cooperation Agency, Tokyo, Japan \\
\hline KEPHIS & Kenya Plant Health Inspectorate Service, Nairobi, Kenya \\
\hline MSU & Michigan State University, East Lansing-MI, USA \\
\hline NACGRAB & $\begin{array}{l}\text { National Centre for Genetic Resources and Biotechnology, Ibadan, Oyo State, } \\
\text { Nigeria }\end{array}$ \\
\hline NAERLS & $\begin{array}{l}\text { National Agricultural Extension and Research Liaison Services, Zaria, Kaduna } \\
\text { State, Nigeria }\end{array}$ \\
\hline NAQS & Nigeria Agricultural Quarantine Service, Abuja, FCT, Nigeria \\
\hline NASC & National Agricultural Seeds Council, Abuja, FCT, Nigeria \\
\hline NBS & National Bureau of Statistics, Abuja, FCT, Nigeria \\
\hline NESG & National Economic Summit Group, Lagos, Lagos State, Nigeria \\
\hline NEPC & Nigeria Export Promotion Council \\
\hline OECD & Organisation for Economic Co-operation and Development, Paris, France \\
\hline RVO & Netherlands Enterprise Agency, The Hague, the Netherlands \\
\hline SANSOR & South African National Seed Organization, Pretoria, South Africa \\
\hline SCCI & Seed Control and Certification Institute, Lusaka, Zambia \\
\hline
\end{tabular}


SEEDAN

STAK

TASAI

UPOV

USAID

WCDI

WECR

WUR
Seed Entrepreneurs Association of Nigeria, Abuja, FCT, Nigeria Seed Trade Association of Kenya

The African Seed Access Index, Cornell University, Ithaca-NY, USA International Union for the Protection of New Varieties of Plants, Geneva, Switzerland

United States Agency for International Development, Washington-DC, USA Wageningen Centre for Development Innovation, Wageningen University \& Research, Wageningen, the Netherlands

Wageningen Economic Research, the Hague, the Netherlands

Wageningen University \& Research, Wageningen, the Netherlands 


\section{Executive summary}

The National Seed Road Map (NSRM) is a strategic policy document that guides stakeholders in the seed sector of Nigeria to work towards an increase in farmers' access to and use of quality seed of improved varieties. The document is a critical input to the development of major agricultural policies of the government, while it can also guide the government, stakeholders and development partners in exploring and agreeing on ways to foster the development of the sector in a coordinated, aligned and structured fashion. The NSRM includes a vision, describes current achievements and challenges, and outlines ambitions and strategic innovation pathways contributing to the realization of those ambitions. The NSRM document is structured by three primary questions on seed sector performance: (i) Where are we now? (ii) Where do we want to go? and (iii) How will we get there?

The policy context is framed by the Agricultural Promotion Policy (APP; 2016-2020), the recently amended National Agricultural Seeds Council Act (NASC; 2019) and the new strategic plan of NASC (2019). The Federal Ministry of Agriculture and Rural Development (FMARD) is currently in the process of reviewing its policy document; the NSRM is a resource for that effort.

Stakeholders in the seed sector include a high number and diversity of government organizations, industry, and knowledge organizations (including research organizations and universities), regulatory bodies, civil society organizations (CSOs) and farmer organizations. 314 formally registered seed companies, of which the majority annually processes less than 1,000 metric tons of seed of grain crops, together with agro-dealers shape the formal and commercial seed system. Individual and mostly unorganized seed producers, community-based seed production schemes and various types of seed entrepreneurs, like informal seed traders, primarily shape the intermediary and informal seed systems. The Seed Entrepreneurs Association of Nigeria (SEEDAN) is the country's seed trade association, with 72 seed companies registered as members in 2019. National Agricultural Research Institutes (NARIs) and CGIAR Research Centers are important for the development of new crop varieties for most food crops as well as for the production of early generation seed (EGS); the private sector constitutes $13 \%$ of variety releases in the seed market. The NASC is the government body responsible for promoting and stimulating the development of a dependable seed industry, regulating and controlling seed registration and release, protecting farmers from the sale of poor-quality seed, and facilitating the production and marketing of high-quality seed.

Despite the operations, infrastructure and economies of scale of a wide diversity of seed sector stakeholders, farmers' access to and use of quality seed of new and improved varieties farmer remains limited, which contributes to crop productivity in Nigeria continuing to be low. The gap between demand and supply of quality seed of improved varieties continues to be more than $90-95 \%$ for all crops, except for open-pollinated maize varieties for which the market is saturated.

The NSRM as a document is the result of a consultative process involving domestic and international stakeholders critical to the sector. It was formulated and compiled through a participatory and iterative process that included a desk study, crop and crop group-based focus group discussions, expert consultations, a multi-stakeholder workshop, and a review by national and international resource persons.

The framework for seed sector transformation guided the review. Where other assessment frameworks focus on individual crops or value chains, specific seed systems, technological innovations or stakeholders, seed sector transformation looks beyond - it applies "systems' thinking", i.e. it takes a holistic approach with complementary strategies for the development of the seed sector as a whole. The framework considers that a well-performing seed sector needs a strong production base; it needs to perform well in relation to the functions of (i) service provision, (ii) seed production, and (iii) market development. This production base requires strong governance, and the sector needs to perform well in 
relation to the functions of (iv) revenue generation and reinvestment, ( $v$ ) coordination and governance, and $(\mathrm{vi})$ regulation and management.

The NSRM as a strategic document identifies challenges that are placed within the above-mentioned six functions of seed sector transformation. No single response exists to the question, "Where are we now?", because the structure of the seed sector, and the diversity of crops and situations therein, is too complex. Rather, the assembly of challenges structured along the six functions responds to this question.

The challenges have been synthesized and transformed into ambitions, which are descriptions of a desired state or outcome of a transformation process. The collection of ambitions within each of the six functions shape a future vision in which the seed sector becomes high performing in ensuring access to and availability and use of quality seed of improved varieties of all crops for farmers.

The vision for the seed sector in Nigeria is to be competitive, resilient, profitable, innovative and adaptive, sustainable, inclusive, resistant and transparent.

An assembly of 22 prioritized topics, with their ambitions grouped along the six seed sector performance functions, shapes the response to the NSRM's guiding question, "Where do we want to go?". The ambitions that are marked as general, i.e. relevant to the entire seed sector and all crops, are elaborated in the NSRM. However, it should be noted that ambitions can be specific to certain crops or crop groups. Table 1 illustrates the 22 prioritized topics for each of the ambitions across the six functions.

Table 1 National Seed Road Map - presentation of the topics associated with ambitions for seed sector transformation

\begin{tabular}{|c|c|c|}
\hline Service provision & Production systems & Market development \\
\hline $\begin{array}{l}\text { The seed sector is capable of providing } \\
\text { high quality, inclusive and } \\
\text { differentiated services to seed } \\
\text { producers and seed value chain actors }\end{array}$ & $\begin{array}{l}\text { The seed sector has viable and } \\
\text { sustainable seed production systems for } \\
\text { all crops }\end{array}$ & $\begin{array}{l}\text { The seed sector has efficient, fair and } \\
\text { transparent seed value chains and seed } \\
\text { markets }\end{array}$ \\
\hline $\begin{array}{l}\text { - Decentralization of seed quality } \\
\text { assurance } \\
\text { - Professional variety development }\end{array}$ & $\begin{array}{l}\text { - Early generation seed supply } \\
\text { - Infrastructural capacity for seed } \\
\text { production \& marketing } \\
\text { - Company professionalization \& } \\
\text { specialization } \\
\text { - Community-based seed production }\end{array}$ & $\begin{array}{l}\text { - Extension on seed \& cultivation } \\
\text { practices } \\
\text { - Tackling of counterfeit seed } \\
\text { - Seed company marketing \& } \\
\text { promotion } \\
\text { - Crop value chains \& food security } \\
\text { - policies stimulating seed demand } \\
\text { - Seed distribution networks } \\
\text { - Institutional markets }\end{array}$ \\
\hline $\begin{array}{l}\text { The seed sector has the capacity to } \\
\text { generate revenues and make strategic } \\
\text { reinvestments }\end{array}$ & $\begin{array}{l}\text { The seed sector has appropriate } \\
\text { coordination and governance } \\
\text { mechanisms in place, which result in } \\
\text { alignment and accountability among } \\
\text { different seed stakeholders }\end{array}$ & $\begin{array}{l}\text { The seed sector has rules and systems } \\
\text { in place that govern seed markets, } \\
\text { production systems, service provision } \\
\text { and coordination }\end{array}$ \\
\hline $\begin{array}{l}\text { - Revenue generation for seed quality } \\
\text { assurance services } \\
\text { - Financial services \& products }\end{array}$ & $\begin{array}{l}\text { - Sector governance \& coordination } \\
\text { - Seed information } \\
\text { - Seed trade association } \\
\text { - Alignment of donor interventions }\end{array}$ & $\begin{array}{l}\text { - Plant variety protection } \\
\text { - Variety release } \\
\text { - Seed import } \\
\text { - Seed export }\end{array}$ \\
\hline
\end{tabular}

The core of the NSRM responds to the final question, "How will we get there?". For each of the 22 topics, the document provides a detailed description of the ambitions and associated challenges. Through what is referred to as strategic innovation pathways, the document elaborates for each topic a maximum of five steps/activity groups, unfolding what can be done to achieve the ambition in a 
sustainable manner. The stakeholders critical to achieving each ambition are mentioned. A catalyst, i.e. an organization that is in the best position to initiate and facilitate the change process, is proposed. Furthermore, each pathway provides reference to the primary policy documents, including the APP (2016-2020), the NASC Act (2019) and the NASC's five-year strategy (2020-2024). To make changes tangible, for each of the pathways a two-, five- and/or ten-year horizon is described. To illustrate that the proposed pathways are not isolated from developments in Nigeria, Africa and other regions of the world, the description of the pathway concludes with illustrative examples of systemic change processes or situations in which similar ambitions have been achieved. 


\section{Glossary}

\begin{tabular}{|c|c|}
\hline Accre & $\begin{array}{l}\text { Delegation of responsibility to a party other than the officially responsible government authority; for } \\
\text { example, delegation of responsibility for seed certification. }\end{array}$ \\
\hline $\begin{array}{l}\text { Advanced } \\
\text { cultivation practices }\end{array}$ & $\begin{array}{l}\text { Improved practices in crop production that result in increased productivity and crop quality. } \\
\text { Improvements relate to the use of quality seed and improved varieties, agro-ecologically specific and } \\
\text { crop-specific fertilizers and crop protection products, and irrigation and other agronomic practices. }\end{array}$ \\
\hline $\begin{array}{l}\text { Agriculture } \\
\text { Promotion Policy } \\
(2016-2020)\end{array}$ & $\begin{array}{l}\text { Strategy of the Federal Ministry of Agriculture and Rural Development guiding agricultural } \\
\text { development with the purpose to produce enough high-quality foods for the Nigerian market, } \\
\text { successfully serve the export market, and generate foreign exchange earnings (FMARD, 2016). }\end{array}$ \\
\hline $\begin{array}{l}\text { Agricultural value } \\
\text { chain }\end{array}$ & $\begin{array}{l}\text { The people and activities that bring an agricultural product from the farmer's field to the consumer, } \\
\text { through stages such as processing, packaging and distribution. }\end{array}$ \\
\hline $\begin{array}{l}\text { Agricultural value } \\
\text { chain programme }\end{array}$ & $\begin{array}{l}\text { Donor-supported programmes promoting the development of agricultural value chains for food, } \\
\text { livestock, fisheries and artisan products, addressing production, processing, marketing and finance. }\end{array}$ \\
\hline Breeder seed & $\begin{array}{l}\text { The seed class produced by the breeder/owner of the variety, or his or her agent, under the plant } \\
\text { breeder's supervision; this seed is used to produce foundation seed. }\end{array}$ \\
\hline Busir & $\begin{array}{l}\text { A business plan lays out the basic idea for a venture, describing where a business is now, indicating } \\
\text { where it wants to go, and outlining how to get there, including a clear evaluation of the viability of } \\
\text { the venture as well as success factors. }\end{array}$ \\
\hline $\mathrm{Ce}$ & $\begin{array}{l}\text { seed class produced from foundation seed, which has been inspected and tested to ensure it } \\
\text { neres to minimum quality standards, and which is sold to farmers for crop production. }\end{array}$ \\
\hline $\begin{array}{l}\text { Development } \\
\text { partner }\end{array}$ & $\begin{array}{l}\text { Donor organization, or its executive agency, which collaborates with federal or state governments } \\
\text { and other stakeholders in the development of the country and/or specific sectors like the agricultural } \\
\text { sector. }\end{array}$ \\
\hline DUS & $\begin{array}{l}\text { testing of new varieties for distinctiveness, uniformity (homogeneity) and stability for the } \\
\text { pose of granting plant breeders' rights. }\end{array}$ \\
\hline $\begin{array}{l}\text { Early generation } \\
\text { seed }\end{array}$ & $\begin{array}{l}\text { The classes of breeder seed and foundation seed used as the basis for the production of } \\
\text { certified/quality seed. }\end{array}$ \\
\hline Farmer group & $\begin{array}{l}\text { An organized group of farmers that jointly engage in an agricultural enterprise, such as seed } \\
\text { production; the number of members in each farmer group varies; the group may or may not be } \\
\text { registered. }\end{array}$ \\
\hline Farme & $\begin{array}{l}\text { Seed harvested from the farmer's crop used as input for the next cropping season; farmers may save } \\
\text { seed for their own use or may exchange or even sell seed to others. }\end{array}$ \\
\hline Field & $\begin{array}{l}\text { pection of a seed field as part of a seed certification scheme to check on isolation, seed crop } \\
\text { nagement, hectarage of the seed field, presence of diseases and weeds, off-types and varietal } \\
\text { ntity. }\end{array}$ \\
\hline Forma & $\begin{array}{l}\text { Seed supply that involves specialized activities of the seed value chain by breeders, producers of } \\
\text { early generation seed, seed producers, and marketing agents, governed by an official regulatory } \\
\text { environment. Seed in formal systems is mostly certified and activities along the seed value chain are } \\
\text { to a large extent commercialized. }\end{array}$ \\
\hline undation seed & $\begin{array}{l}\text { The seed class produced from breeder seed, grown by or under the supervision of a plant breeder or } \\
\text { his or her agent for use in the production of certified seed. }\end{array}$ \\
\hline Hybrid variety & $\begin{array}{l}\text { A variety of which the seed is produced by controlled crossing of two or more parental lines with } \\
\text { contrasting characters, resulting in uniform and more vigorous progenies; when reproduced in a non- } \\
\text { controlled manner, parental characters get segregated and the variety loses its uniformity and } \\
\text { vigour. }\end{array}$ \\
\hline $\begin{array}{l}\text { Informal } \\
\text { systems }\end{array}$ & $\begin{array}{l}\text { Seed supply that includes the activities of farmers, rural communities and other stakeholders saving, } \\
\text { exchanging, bartering, gifting and selling seed without formal regulatory involvement and varying } \\
\text { degrees of commercial orientation. }\end{array}$ \\
\hline Instit & $\begin{array}{l}\text { Government agencies, non-governmental organizations (NGOs) and projects that purchase seed in } \\
\text { large quantities and subsequently disseminate or market the seed to farmers within private sector } \\
\text { development or agricultural value chain programmes with the aim of boosting production and } \\
\text { increasing productivity, or in food security or humanitarian programmes with the aim of enhancing } \\
\text { food and/or nutrition security of rural populations. }\end{array}$ \\
\hline $\begin{array}{l}\text { Integrated seed } \\
\text { sector development }\end{array}$ & $\begin{array}{l}\text { A pluralistic approach that recognizes the relevance of formal and informal seed systems and aims to } \\
\text { balance public- and private-sector involvement; it replaces a linear or blue-print approach towards } \\
\text { the development of fully commercial and formal seed systems. }\end{array}$ \\
\hline
\end{tabular}


Intermediary seed Seed supply that involves individual seed entrepreneurs and organized groups of seed producers and

systems entrepreneurs and/or their associations, that are engaged in commercial seed production and marketing, with loose or temporary linkages to formal organizations including research, extension, markets, financial services, seed quality assurance and other regulations.

Local seed An individual, organization or company that engages in seed business in terms of production and/or entrepreneur marketing of seed, operating within informal and intermediary seed systems in which seed quality assurance is based on trust.

NASC Strategy Five-year strategic plan to guide the growth and development of the National Agricultural Seeds

(2020-2024) Council (NASC) between 2020 and 2024, including vision and mission statements as well as three core strategic objectives, and key implementation strategies, with activities, required resources, key performance indicators, timelines and suggested departments to drive execution (NASC, 2019).

National Agricultural Seeds Council Act (2019)

\section{Open-pollinated}

variety Plant breeders' rights Plant variety protection Private sector development programme Quality seed Bill that enacts the NASC to promote and stimulate the development of a dependable seed industry, regulate and control the registration of released varieties, protect the farmers from the sale of poorquality seed, facilitate the production and marketing of high quality seed in Nigeria and provide legal backing for official testing, certification, sales, importation, exportation and use of seed and related matters (FMARD, 2019).

Variety multiplied through random pollination/fertilization, i.e. in contrast to hybrid varieties for which the crossing of parental lines is controlled.

The legal right of the originator of a new crop variety within a plant variety protection system.

Legal system of granting exclusive rights over varieties to the originator, i.e. the breeder or discoverer.

Donor-supported programmes implemented by the federal or state governments with other stakeholders in order to promote the private sector in agriculture, including collaborations with large multinational companies and the development of small- and medium-sized enterprises.

Seed that is varietally pure with a high germination percentage, free from diseases, and with a proper moisture content and weight. The use of quality seed ensures good germination, rapid emergence, and vigorous growth of the crop. Quality seed can be purchased as certified seed through commercial channels, but also obtained from informal sources.

Seed Part of the crop used for propagation either as a seed in a botanical sense, which is developed from a fertilized ovule, as a seedling, or as other parts such as a corn, cutting, bulb, root, scion, tuber or stem, used for vegetative propagation.

Seed certification Assuring a minimum level of seed quality by an official certifying agency, including field inspection and seed testing; classes of certified seed include breeder seed, foundation seed and certified seed.

Seed company A company that engages in seed business in terms of production and/or marketing of certified seed of registered varieties, which is registered with the NASC; such entrepreneurs operate within formal seed systems.

Seed entrepreneur An individual, company or organization that engages in seed business in terms of production and/or marketing of seed independent of whether operating in formal, intermediary or informal seed systems.

Seed processing All the treatments that the seed is subjected to other than laboratory seed testing between harvesting and sale, aimed at maximizing seed viability, vigour and health, including drying, threshing, (pre)cleaning, size grading, treating, packaging and labelling.

Seed producer An individual, organization or company that grows a crop intended to produce seed, is registered as such with the NASC, and is enrolled in seed certification or other approved quality assurance mechanism.

Seed quality The sum of all factors such as varietal purity, seed health, germination, moisture content and vigour which affect the performance of the seed crop.

Seed quality The assurance of varietal identity and purity, viability in terms of physiological and health conditions, assurance and other standards in seed production and processing through control, inspection and labelling; including certification through NASC and/or accredited third parties.

Seed sector Within the framework of seed sector transformation, six functions cover the production base and function governance; the performance of a sector is dependent on all functions; in the assessment framework, all functions are considered and reviewed, identifying challenges and ambitions for the stage desired.

Seed sector An assessment framework that applies a holistic approach with complementary strategies for the transformation development of the seed sector as a whole; it considers the sector's need for a strong production framework base and performance in relation to the functions of (i) service provision, (ii) seed production, and (iii) market development; as well as the need for strong governance and performance in relation to the functions of (iv) revenue generation and reinvestment, (v) coordination, and (vi) regulation and management. 


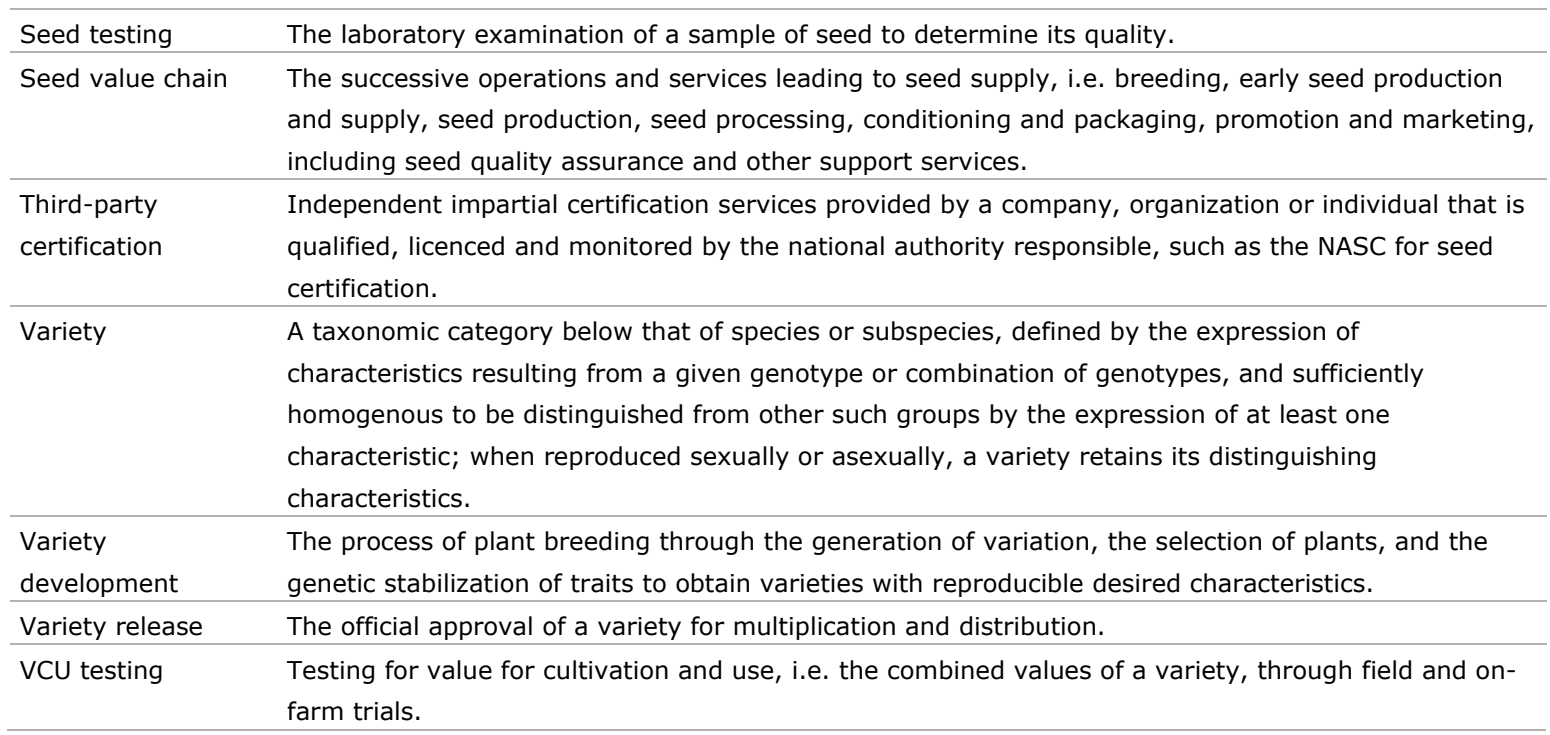




\section{Introduction}

\section{$1.1 \quad$ Purpose}

The National Seed Road Map (NSRM) is a strategic policy document that guides stakeholders in the seed sector of Nigeria to work towards a seed sector that increases farmers' access to and use of quality seed of improved varieties. The document is a critical input in the development of major agricultural policies of the government, while also guiding the seed industry and other seed sector stakeholders. Moreover, the NSRM can serve as a reference for collaboration between the government, stakeholders and development partners, guiding them in exploring and agreeing on ways to foster the development of the sector in a coordinated, aligned and structured fashion. The document includes a vision, describes current achievements and challenges, and outlines ambitions and strategic innovation pathways, which contribute to the realization of those ambitions. The following questions for seed sector performance structure the document: (i) Where are we now? (ii) Where do we want to go? and (iii) How will we get there?

\subsection{Guiding seed sector transformation}

The NSRM is the result of a participatory and iterative process referred to as a seed sector review or assessment. A team of international and Nigerian consultants, further referred to as 'the consultancy team' implemented the assessment. The review included a desk study, focus group discussions (FDGs) and a multi-stakeholder workshop. Both Nigerian and international experts were consulted during several steps of the process. Moreover, critical development partners of the Federal Government of Nigeria (e.g. donors and international development organizations) were consulted. The team has used a framework for guiding sector transformation (Aidenvironment et al. 2017) to support the development of the NSRM. Box 1 provides more insights into this framework. 
Box 1. Seed sector transformation

Inspired by the approach of integrated seed sector development (ISSD)

(WUR, 2020), seed sector

transformation moves away from linear thinking, i.e. it realizes that seed systems for different crops face different challenges. It looks beyond individual crop value chains and applies "systems' thinking", i.e. a holistic approach with complementary strategies for the development of the seed sector as a whole. The

framework uses the future vision as the point of departure, and not today's problems. To perform well the sector needs a strong production base, and it needs to perform well in relation to the functions of (i) service provision, (ii) seed production and (iii) market development. This production base needs to be complemented with strong governance; the sector needs to perform well in relation to the functions of (iv) revenue generation and reinvestment, ( $v$ ) coordination, and (vi) regulation and management. A seed sector assessment identifies challenges that are placed within the six functions. The challenges are synthesized and transformed into ambitions. The combined ambitions within the six functions shape a future vision in which the seed sector becomes high performing in ensuring the availability of, access to and use of quality seed of all crops by farmers.

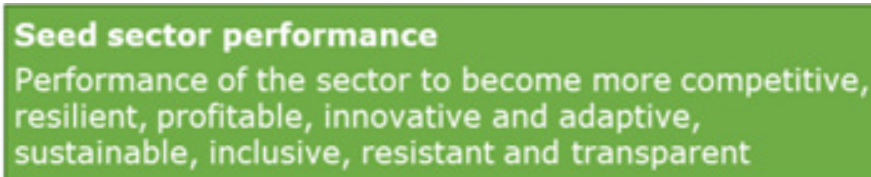

Service provision

The capacity of the

seed sector to

provide high

quality, inclusive

and differentiated

services to seed

producers $\&$ seed

value chain actors

\section{Seed}

production

systems

The viability

and

sustainability of

seed production

systems

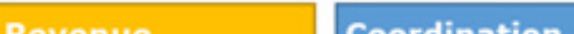

Revenus:

generation 8 .

The capacity of the

seed sector to

generate revenues

and make strategic

reinvestments

Coordination

\& governance

The degree of

coordination,

alignment and

accountability

among different

seed

stakeholders

Seed market

development

The efficiency,

fairness and

transparency of

seed value

chains and seed

markets

\section{Regulation \&}

management

Rules and

systems that

govern seed

markets,

production

systems,

service delivery

and reinvestment

coordination 


\section{$2 \quad$ Where are we now?}

\subsection{Agricultural development}

Despite 50 years of significant investments in crop improvement and formal seed system development, more than $90 \%$ of the seed used by farmers in sub-Saharan Africa (SSA) is obtained from informal seed sources. Crop productivity in SSA is considerably lower than in other continents (see Figure 1). The Global Yield Gap Atlas (2020) illustrates the difference between potential yields and yields achieved in practice with the example of maize and rainfed rice in Nigeria, where the gap is more than $250 \%$. It is estimated that $50 \%$ of the yield gap can be closed with the use of quality seed of improved and/or hybrid varieties; the other $50 \%$ through the application of good agronomic practices and the use of fertilizers. The percentage of Nigerian farmers using quality seed of improved varieties is below 15\% (TASAI, 2019).

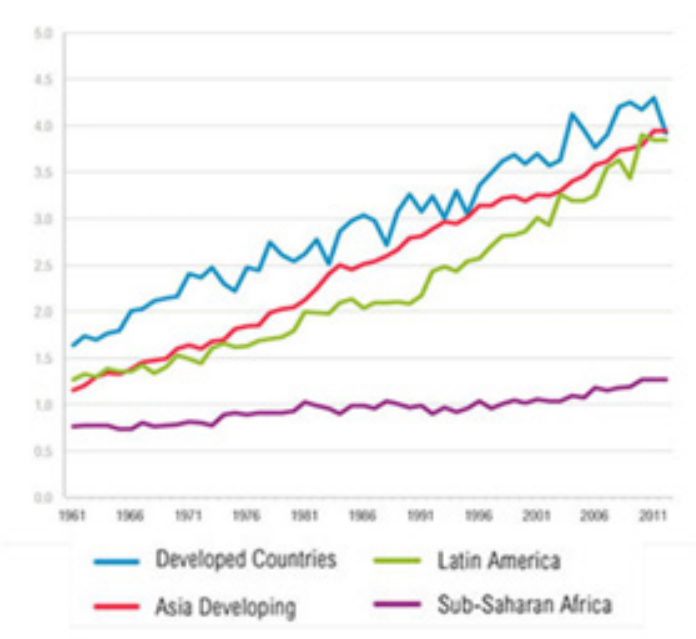

Figure 1 Cereal yields - global trends

\subsection{Policy context}

\section{Agricultural sector}

The Agriculture Promotion Policy (APP, 2016-2020) (FMARD, 2016), the policy document for the agricultural sector of the previous government, considers the agricultural sector a key instrument to long-term economic growth. The APP promotes reinforcing private sector-led agribusiness; strengthening of commodity value chains; improving market orientation through infrastructure and commodity exchanges; mainstreaming climate change measures; and implementing nutrition interventions for vulnerable groups. The APP, within its "Access to inputs" section, aims to increase the availability of and access to quality seed through strengthening seed policies, leveraging global expertise and facilitating private sector development. The FMARD is currently in the process of reviewing its policy document; the NSRM is a resource for that effort.

\section{Seed sector}

Prior to 2019, the main legal documents guiding the development of the seed sector in Nigeria were the National Seeds Decree of 1992 and the National Agricultural Seeds Act, Cap N5 of 2004. In 2015, the national seed policy was passed, which provides a framework to encourage private sector participation, fast-track variety development, registration and release, and improve the quality of seed available to farmers. The 2004 Act was repealed and has been replaced by the National Agricultural 
Seeds Council Act of 2019 (FMARD, 2019). This Act was passed by the House of Representatives in December 2018, passed by the Senate in April 2019, and given Presidential assent in June 2019. The Act consolidates the establishment of the National Agricultural Seeds Council (NASC) with the responsibility to promote and stimulate the development of a dependable seed industry, regulate and control seed production, support variety registration and release, protect farmers from the sale of poor-quality seed, and facilitate the production and marketing of high-quality seed. In addition, it promotes greater participation of the private sector in the seed industry. As member of the Economic Community of West African States (ECOWAS), Nigeria's 2019 NASC Act conforms with the ECOWAS Seed Regulation (C/Reg.4/05/2008), passed in 2008. For example, the NASC Act elaborates standards for seed certification in compliance with ECOWAS regulations and institutes a National Seed Catalogue with the ECOWAS Catalogue of Plant Species and Varieties as reference. However, in contrast to ECOWAS, harmonization on variety release is not yet implemented.

Nigeria is signatory to various international treaties of the Food and Agriculture Organization of the United Nations, and to the Agreement on Trade-Related Aspects of Intellectual Property Rights (TRIPS). Work is ongoing to get approval of a law for plant variety protection (PVP) that will be in line with the International Convention for the Protection of New Varieties of Plants (UPOV Convention, 1991).

The strategic plan of the National Agricultural Seeds Council (2020-2024) (NASC, 2019) guides the organization's growth and development between 2020 and 2024. The strategy aims to enhance service delivery by the NASC and increase its financial sustainability and operational effectiveness. The strategy is expected to result in more timely and cost-efficient certification processes; increased availability of quality seed, and a $40 \%$ increase in farmer adoption; reduced counterfeiting; the recognition of the NASC as a point of reference for the seed industry; enhanced capacity of key industry stakeholders and NASC staff; and diversification of revenue streams and reduction in operational costs by the NASC.

\subsection{Seed sector stakeholders}

The seed sector includes government organizations, industry, and knowledge organizations (e.g. agricultural research institutes and universities), regulatory bodies, civil society organizations and farmer organizations. The diversity and number of stakeholders shows that the sector is vibrant and in a process of growth and development. Several international and domestic research organizations operating in the public domain are responsible for variety development and evaluation; they also engage in the production and supply of early generation seed (EGS) of improved varieties. These organizations include national agricultural research institutes (NARIs), international agricultural research institutes (e.g., the International Institute of Tropical Agriculture - IITA; the International Crops Research Institute for the Semi-Arid Tropics - ICRISAT; and AfricaRice), state government agricultural departments and universities (e.g. Ahmadu Bello University). The industry includes foreign and domestic seed companies, community-based seed production schemes, other local seed entrepreneurs and agro-dealers. They engage in the production and/or marketing of quality seed. According to the NASC, there are currently 314 registered seed companies in Nigeria, with the majority producing fewer than 1,000 metric tons of seeds annually. Development partners, through NGOs and projects, are engaged in the promotion and dissemination of quality seed of improved varieties. The NASC is the government entity responsible for regulating seed in Nigeria (see Section 2.2). The Nigeria Agricultural Quarantine Service (NAQS) is responsible for phytosanitary aspects in the sector. The National Crop Varieties and Livestock Breeds Registration and Release Committee (NCVLBRRC), hosted by the National Centre for Genetic Resources and Biotechnology (NACGRAB), is responsible for the release of crop varieties. The Seed Entrepreneurs Association of Nigeria (SEEDAN) brings together seed companies and other key private sector players in the industry; the association currently has 72 registered members. 


\subsection{Farmers' current seed sources}

Based on a desk study and focus group discussions (FGDs) as part of the seed sector review, the consultancy team has compiled an overview of farmers' current seed sources (see Figure 2). It illustrates the predominance of farmer-saved seed, with the exception of maize hybrid varieties (HVs). Whereas commercial certified seed is readily available for open-pollinated varieties (OPVs) of maize, it is only available to a limited extent for the other crops/crop groups. For rice, as well as legumes and small grains, community-based seed schemes are a source of seed. Informal markets are currently the most important source of seed for various crops/crop groups, although the quality of the seed is often no different to that of grain.

\begin{tabular}{|c|c|c|c|c|}
\hline \multirow[t]{2}{*}{ Crop group } & $\begin{array}{l}\text { Certified seed } \\
\text { from companies }\end{array}$ & $\begin{array}{l}\text { Quality seed } \\
\text { from community } \\
\text { based schemes }\end{array}$ & $\begin{array}{l}\text { Seed from informal } \\
\text { markets }\end{array}$ & $\begin{array}{l}\text { Farmer saved } \\
\text { seed }\end{array}$ \\
\hline & Formal & & & Informal \\
\hline Maize HV & ; & & & \\
\hline Maize OPV & 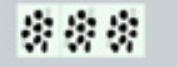 & & ; & ; \\
\hline Rice & ; & ; & ; & ;: \\
\hline $\begin{array}{l}\text { Legumes \& small } \\
\text { grains }\end{array}$ & ; & ; & ; & : \\
\hline RTBs & 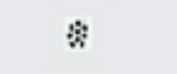 & 6 & : & : \\
\hline Vegetables & ; & & ; & ; \\
\hline
\end{tabular}

Figure 2 Farmers' seed sources for various crops and crop groups

\subsection{The seed gap}

During the FGDs, as part of the seed sector review, groups of crop and seed experts engaged in making projections for crop production and seed demand. Based on FAOSTAT data for 2010 and 2015, and expectations of the experts in relation to future development and demand for the crop, the experts estimated for a number of indicator crops, cropping area, crop production and crop productivity for 2020, 2025 and 2030. Subsequently, they calculated seed demand for the same years (see Table 2). While the market for maize OPVs seems saturated, huge seed gaps are expected for the other crops for 2020 as well as for 2025 and 2030. Since the market for quality tomato seed is dominated by the procurement of seed produced by international and regional companies, the consultancy team did not consider seed production and the seed gap for this crop. The projections assisted in the identification of challenges and opportunities for improving the performance of the seed sector for the following crop groups: maize; legumes, rice and small grains; roots, tubers and bananas (RTBs); and vegetables. More details on the assumptions for the projections can be found in the crop briefs (WUR, 2019a) that have been developed as part of the seed sector review. 
Table 2 Seed gap projections for various crops as elaborated during FGDs for the seed sector review

\begin{tabular}{|c|c|c|c|c|c|}
\hline \multirow[b]{2}{*}{ Crop } & \multicolumn{3}{|c|}{2020} & $\begin{array}{c}2025 \\
\text { Seed gap }\end{array}$ & $\begin{array}{c}2030 \\
\text { Seed gap }\end{array}$ \\
\hline & Metric ton (MT) & MT & $\%$ & $\%$ & $\%$ \\
\hline Maize OPV & 26,088 & 27,811 & -7 & 0 & 0 \\
\hline Cowpea & 9,710 & 1,940 & 80 & 75 & 70 \\
\hline Yam & 10,000 & NA* & 100 & 99 & 90 \\
\hline Irish potato & 288,620 & 2,886 & 99 & 98 & 96 \\
\hline Tomato HV & 21 & $\mathrm{NA}+$ & NA & NA & NA \\
\hline Tomato OPV & 126 & $\mathrm{NA}+$ & NA & NA & NA \\
\hline
\end{tabular}

* Currently, yam seed production is informal; seed value chain for improved varieties is not yet operational

+ Tomato seed is primarily imported from regionally and globally operating seed companies

\subsection{Seed sector challenges}

Enhancing the availability, access to and use of quality seed is complex. Seed needs to be:

(i) physically available in sufficient quantity at the right place and time; (ii) accessible at an affordable price; and (iii) to be of a variety well suited to the local agro-ecological conditions, and to farmer and market demands. Farmers access and use seed from several sources or seed systems. Each seed system has its own strengths and weaknesses. To strengthen the performance of a seed sector, each seed system requires targeted interventions for improvement.

The estimated seed gaps, together with insights of resource persons shared during FGDs and individual consultations, informed the consultancy team in the identification of challenges that negatively impact the performance of the seed sector. Additional challenges were identified based on key references like the Enabling the Business of Agriculture report for Nigeria (EBA, 2017), the African Seed Access Index: Nigeria Brief (TASAI, 2019) and the Access to Seeds Index: Western and Central Africa report (AtSI, 2019). The challenges identified were grouped and structured according to the six functions for seed sector transformation. The team indicated if challenges are important to all crops, or if they are crop/crop group specific. Challenges have been verified through a review of the assessment report (WUR, 2019b) by all experts involved in the prior consultations. The challenges for each of the six seed sector performance functions are outlined below. It should be noted that only the challenges that are general for all crops are presented; the challenges that are specific to crops and crop groups are presented in the assessment report. A total of 84 challenges, related to 34 different topics, were identified.

\section{Service provision}

- A disconnect between research and farmers reduces variety adoption

- Due to the limited capacity of research institutions, research results are not compelling and do not lead to significant economic gains

- Constrained capacity and infrastructure of research organizations results in inefficient variety release procedures

- Infrastructural and technical capacity for variety development and EGS supply at NARIs is limited

- Seed producers and seed companies do not have sufficient access to seed quality assurance services

- Seed companies do not have access to financial products and services for their production and marketing operations

- Business support services to seed companies are not available

- Low extensionist/farmer ratio and limited involvement of seed companies in extension limit farmers access to seed related knowledge and information. 


\section{Seed production systems}

- The capacity of seed companies in production, marketing, and financial management is limited

- Seed companies and seed producers are constrained in their infrastructural capacity

- Seed companies do not have access to accurate industry/market information to inform proper production planning

- Structure and processes for EGS supply are constrained and hamper variety deployment and replacement

- EGS-demand forecasting systems that inform future EGS needs of companies are not available

- Predominance of institutional markets for several crops results in seed market inefficiencies and carryover seed

- The presence of non-genuine seed companies and traders hampers the development of the sector.

\section{Seed market development}

- Weak crop value chain structure and operation, combined with inefficient crop production practices, result in farmers investing to a limited degree in quality seed of new and better-performing varieties

- Instability in grain markets reduces farmers' willingness to invest in crop production, including the purchase of quality seed

- Farmers have limited awareness of quality seed and improved varieties; they do not use advanced practices required for their successful cultivation

- Limited investment by seed companies in seed marketing and promotion reduces quality seed uptake by farmers

- Weak commercial seed distribution networks fail to reach farmers with adequate quantities of seed at the right time

- Several agro-dealers are engaged in the marketing of fake seed

- Farmers and agro-dealers are not able to distinguish fake seed from quality seed

- Farmers consider purchasing certified seed a risk, due to their limited trust in seed companies/agrodealers

- NGO/government subsidies/distribution schemes hinder farmers' willingness to pay for quality seed, hamper the functioning of seed markets and create imbalanced opportunities for national and international seed companies.

\section{Revenue generation and reinvestment}

- Relatively high costs of proprietary variety release and required breeder involvement constrain seed companies releasing varieties and therefore hamper competition

- The extent of seed-quality assurance services is dependent on government and project budgets; the system is not based on service-based revenues

- Seed companies have a short-term business perspective; they save and invest financial resources to only a limited degree

- Given the sector's immature financial status, tailored soft loans, and financial products and services are not available to seed companies and their operations

- Plant variety protection is not yet operational; therefore, private companies are currently reluctant to bring new improved varieties to the Nigerian market

- Government, NGO and project subsidies hamper revenue generation and the sustainability of private companies

- The zero tariffs applied to agricultural inputs is not applicable to seed, impacting on seed prices.

\section{Seed sector coordination}

- A structured seed sector platform, which includes stakeholders from public, private, civil society and knowledge organizations

- Some platforms have been established to support the sector, they are not functional and do not provides platform services

- The performance of the seed sector is hampered by the friction between public and private stakeholders' interests

- Limited coordination in the seed sector leads to individual interventions by donor and development organizations in specific crop value chains, thereby impacting the sector in an uncoordinated fashion

- Sector coordination and governance are jeopardized by the limited availability and reliability of data 
- The NASC has the statutory mandate by law to regulate the seed sector, hence the NASC needs to provide leadership in the implementation of seed systems activities within larger value chains and related programmes

- SEEDAN only has a basic governance structure, and does not have chapters on commodities, regions, or types of seed entrepreneurs; this results in the limited representation of specific demands.

\section{Seed sector regulation and management}

- Public investment in research, crop improvement and seed systems for food security crops is limited or not structural

- The NASC's focus on quality assurance for only a few grain crops impacts the quality of seed available in RTBs and vegetables

- The ECOWAS policy on variety release has not yet been implemented

- Limited enforcement of quality standards makes fake seed a rewarding business

- National seed companies are constrained in seed export due to the current status of the NASC's membership of world seed bodies, such as its observer status with the International Union for the Protection of New Varieties of Plants (UPOV); membership of the Seed Scheme of the Organization for Economic Co-operation and Development (OECD) is at the application stage

- Due to the weak partnership between the NASC and other relevant government agencies, such as the Nigeria Customs Service and the NAQS, the regulation of seed import is poor

- Corruption at ports and borders constrains seed import

- The Plant Variety Protection Bill is close to approval; the system to make PVP operational still needs to be designed and implemented. 


\section{Where do we want to go?}

\section{$3.1 \quad$ Vision}

The vision for the seed sector in Nigeria is to become more competitive, resilient, profitable, innovative and adaptive, sustainable, inclusive, resistant and transparent. The vision is illustrated in Figure 3.

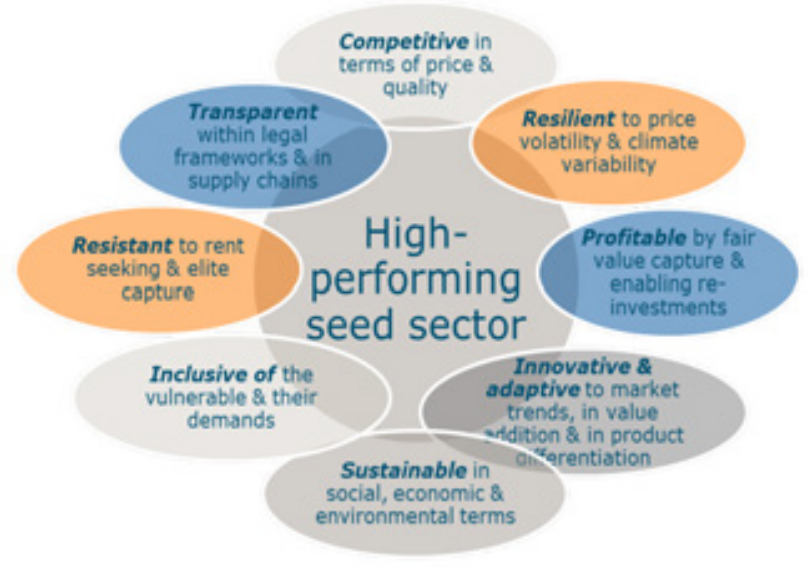

Figure 3 Seed sector vision

\subsection{Selection of topics and ambitions}

Based on the strategies for tackling challenges as identified during the FGDs of the seed sector review, and complemented with information resulting from the desk study, the consultancy team identified and elaborated "ambitions". Ambitions are descriptions of a desired state or outcome of a transformation process. The consultancy team grouped ambitions by topics, and according to the six functions of sector transformation. The team identified 8 topics for service provision; 9 for seed production systems; 9 for seed market development; 11 for revenue generation and reinvestment; 7 for governance and coordination; and 8 for seed sector regulation and management. Like the challenges, topics may be related to several seed sector functions; however, with ambitions specific for the function. The ambitions were marked as general, i.e. relevant to the entire seed sector and all crops, or as specific to certain crop groups, e.g. maize; roots, tubers and bananas (RTBs); legumes, rice and small grains; and vegetables. In the multi-stakeholder workshop (WUR, 2019c), as part of the seed sector review, participants first prioritized topics according to crop group, and secondly according to stakeholder group. A total of 22 topics were prioritized for the NSRM. Further information can be found in the assessment report (WUR, 2019b). Below, the ambitions are listed as 22 prioritized topics, according the six functions. 


\section{Service provision}

\begin{tabular}{ll} 
Ambition for function & $\begin{array}{l}\text { The seed sector is capable of providing high quality, inclusive and differentiated } \\
\text { services to seed producers and seed value chain actors. }\end{array}$ \\
$\begin{array}{ll}\text { Decentralization of seed } \\
\text { quality assurance }\end{array}$ & $\begin{array}{l}\text { Consolidated, effective and sustainable seed quality assurance systems cover multiple crops } \\
\text { (cereals, legumes, RTBs, and vegetables) and provide services to different types of seed } \\
\text { entrepreneurs. Specific seed quality assurance standards and protocols developed and } \\
\text { implemented for all crops, especially for RTBs and vegetables. }\end{array}$ \\
\hline $\begin{array}{l}\text { Professional variety } \\
\text { development }\end{array}$ & $\begin{array}{l}\text { Enhanced public capacity for variety development with functional research, farmer and market } \\
\text { linkages. }\end{array}$ \\
\hline
\end{tabular}

\section{Production systems}

\begin{tabular}{|c|c|}
\hline Ambition for function & The seed sector has viable and sustainable seed production systems for all crops \\
\hline $\begin{array}{l}\text { Early generation seed } \\
\text { supply }\end{array}$ & $\begin{array}{l}\text { Enhanced commercial and sustainable public and private capacity, structures and processes } \\
\text { for early generation seed (EGS) supply including an operational EGS forecasting system. }\end{array}$ \\
\hline $\begin{array}{l}\text { Company } \\
\text { professionalization \& } \\
\text { specialization }\end{array}$ & $\begin{array}{l}\text { Increased professionalization and specialization of seed companies and other seed } \\
\text { entrepreneurs in the production and marketing of seed of specific crops or crop groups. }\end{array}$ \\
\hline $\begin{array}{l}\text { Community-based seed } \\
\text { production }\end{array}$ & $\begin{array}{l}\text { Strengthened community-based seed production (CBSP) schemes and increased availability of } \\
\text { quality seed of major cereals (except maize), legumes, small grains and RTBs, accessible to } \\
\text { farmers; they have evolved into business-oriented, legitimate, legal, institutionally supported } \\
\text { and organized, trustworthy and sustainable stakeholders in the production and marketing of } \\
\text { quality seed of improved varieties. CBSP schemes and local seed entrepreneurs have } \\
\text { structural linkages with public research organizations for access to new improved varieties, } \\
\text { EGS and other technologies; they are also linked to the NASC, using decentralized modalities } \\
\text { for seed quality assurance, and to financial organizations, enhancing their business } \\
\text { orientation, available financial resources and sustainability. }\end{array}$ \\
\hline
\end{tabular}

\section{Market development}

\begin{tabular}{|c|c|}
\hline in & $\begin{array}{l}\text { The seed sector has efficient, fair and transparent seed value chains and seed } \\
\text { markets }\end{array}$ \\
\hline $\begin{array}{l}\text { Extension on seed \& } \\
\text { cultivation practices }\end{array}$ & $\begin{array}{l}\text { Enhanced public and private extension services that promote farmers' use of quality seed of } \\
\text { improved varieties combined with advanced cultivation practices. }\end{array}$ \\
\hline $\begin{array}{l}\text { Tackling of counterfeit } \\
\text { seed }\end{array}$ & $\begin{array}{l}\text { Increased enforcement of quality assurance and penalties for counterfeit seed marketing; } \\
\text { reduced engagement in the marketing of fake seed by seed companies and agro-dealers; } \\
\text { reduced profitability of counterfeit seed and thereby reduced viability of non-genuine seed } \\
\text { companies and agro-dealers; increased farmers' trust in seed companies and agro-dealers. }\end{array}$ \\
\hline $\begin{array}{l}\text { Seed company marketing } \\
\& \text { promotion }\end{array}$ & $\begin{array}{l}\text { Increased and more structural investment by seed companies in the marketing and promotion } \\
\text { of quality seed and improved varieties that results in an increased awareness of farmers and } \\
\text { enhanced willingness to pay for quality seed and improved varieties. }\end{array}$ \\
\hline $\begin{array}{l}\text { Crop value chains \& food } \\
\text { security policies } \\
\text { stimulating seed demand }\end{array}$ & $\begin{array}{l}\text { Enhanced food and nutrition security policies and more stable prices in grain and crop markets } \\
\text { increase farmers' profitability and enable their investment in the production of food crops, thus } \\
\text { contributing to increased use of inputs such as quality seed of improved varieties. }\end{array}$ \\
\hline Institutional markets & $\begin{array}{l}\text { Increased demand- and market-driven, dynamic and functioning seed sector that operates } \\
\text { sustainably with minimal government, NGO and project subsidies and interventions; if } \\
\text { interventions are made, they promote accountability and sustainability. }\end{array}$ \\
\hline
\end{tabular}




\section{Revenue generation \& reinvestment}

\begin{tabular}{ll}
$\begin{array}{l}\text { Ambition for function } \\
\text { The seed sector has the capacity to generate revenues and make strategic } \\
\text { reinvestments }\end{array}$ \\
$\begin{array}{ll}\text { Revenue generation for } \\
\text { seed quality assurance }\end{array}$ & $\begin{array}{l}\text { Enhanced efficiency and effectiveness of the NASC in delivering seed quality assurance } \\
\text { services, which are supported by a sustainable mechanism for generating revenues. }\end{array}$ \\
\hline $\begin{array}{l}\text { Financial services \& } \\
\text { products }\end{array}$ & $\begin{array}{l}\text { Enhanced availability of financial services and products tailored to seed business, and their } \\
\text { increased use by seed companies and producers in their production and marketing operations. }\end{array}$
\end{tabular}

\section{Coordination \& governance}

\begin{tabular}{|c|c|}
\hline Ambition for function & $\begin{array}{l}\text { The seed sector has appropriate coordination and governance mechanisms in place, } \\
\text { which result in alignment and accountability among different seed stakeholders }\end{array}$ \\
\hline $\begin{array}{l}\text { Sector governance \& } \\
\text { coordination }\end{array}$ & $\begin{array}{l}\text { Enhanced governance of the seed sector with institutional responsibilities for governance and } \\
\text { regulation; a structured and functional National Seed Sector Platform; a collaborative and } \\
\text { sector-driven implementation of the NSRM; and improved coordination between public and } \\
\text { private stakeholders in seed sector development. }\end{array}$ \\
\hline
\end{tabular}

\section{Regulation \& management}

\begin{tabular}{ll} 
Ambition for function & $\begin{array}{l}\text { The seed sector has rules and systems in place that govern seed markets, production } \\
\text { systems, service provision and coordination }\end{array}$ \\
\hline Plant variety protection & $\begin{array}{l}\text { Adopted Plant Variety Protection Bill; operational UPOV-PVP system that supports the } \\
\text { development of the seed sector. }\end{array}$ \\
\hline Variety release & $\begin{array}{l}\text { Increased efficiency and transparency in variety release procedures with a more realistic cost- } \\
\text { benefit ratio; enforced ECOWAS harmonization on variety release that supports private sector } \\
\text { investment. }\end{array}$ \\
\hline Seed import & $\begin{array}{l}\text { Increased efficiency, predictability and transparency of seed import procedures and conditions } \\
\text { at pevelopment; zero import tariffs applied to seed of selected crops, similar to other agricultural } \\
\text { inputs. }\end{array}$ \\
\hline Membership of the NASC with international bodies, like UPOV and the OECD Seed Scheme, \\
established and consolidated, thereby supporting seed export; one-stop portal established for \\
seed export.
\end{tabular}




\section{How do we get there?}

\subsection{Strategic innovation pathways}

A strategic innovation pathway (SIP) provides insights into the ambitions and functions of a topic relevant to seed sector transformation. Table 3 provides the structure for the description of a SIP.

Table 3 Structure for the presentation of strategic innovation pathways

\begin{tabular}{|c|c|}
\hline SIP character & Description \\
\hline Ambition & $\begin{array}{l}\text { Description of the desired state or outcome of a transformation process, including a reference to } \\
\text { the primary and secondary functions for seed sector transformation }\end{array}$ \\
\hline $\begin{array}{l}\text { Systemic innovation } \\
\text { pathway }\end{array}$ & $\begin{array}{l}\text { A maximum of five steps/activity groups describing what can be done to achieve the ambition in a } \\
\text { sustainable manner }\end{array}$ \\
\hline Policy reference & $\begin{array}{l}\text { Reference to the key policy documents, i.e. the Agricultural Promotion Policy (2016-2020) } \\
\text { (FMARD, 2016), the NASC Act (2019) (FMARD, 2019) and the NASC strategy (2020-2024) (NASC, } \\
\text { 2019) }\end{array}$ \\
\hline Illustrative examples & $\begin{array}{l}2 \text { or } 3 \text { examples of successful intervention strategies, either in Nigeria or in other countries, that } \\
\text { may be considered as a reference for ways to achieve the ambition using the proposed innovation } \\
\text { pathway }\end{array}$ \\
\hline
\end{tabular}

Even though many of the SIPs are closely related, they may serve different functions and are presented individually in relation to the seed sector transformation function that they fit best. Table 4 provides an overview of the 22 prioritized topics for which SIPs have been developed, including their reference codes. The order of presentation of the SIPS within each function is based on priorities established during the multi-stakeholder workshop (WUR, 2019c), with numbers 1 indicating the highest priority. From section 4.3 to 4.8 , the SIPs are individually elaborated.

Table 4 Overview of the SIP topics within the six functions of seed sector transformation

\begin{tabular}{|c|c|c|}
\hline $\begin{array}{l}\text { Service provision } \\
\text { - SP1: Decentralization of seed quality } \\
\text { assurance } \\
\text { - SP2: Professional variety } \\
\text { development. }\end{array}$ & $\begin{array}{l}\text { Production systems } \\
\text { - PS1: Early generation seed supply } \\
\text { - PS2: Infrastructural capacity for seed } \\
\text { production \& marketing } \\
\text { - PS3: Company professionalization \& } \\
\text { specialization } \\
\text { - PS4: Community-based seed } \\
\text { production. }\end{array}$ & $\begin{array}{l}\text { Market development } \\
\text { - MD1: Extension on seed \& cultivation } \\
\text { practices } \\
\text { - MD2: Tackling of counterfeit seed } \\
\text { - MD3: Seed company marketing \& } \\
\text { promotion } \\
\text { - MD4: Crop value chains \& food } \\
\text { security policies stimulating seed } \\
\text { demand } \\
\text { - MD5: Seed distribution networks } \\
\text { - MD6: Institutional markets. }\end{array}$ \\
\hline $\begin{array}{l}\text { Revenue generation } \& \\
\text { reinvestment } \\
\text { - RR1: Revenue generation for seed } \\
\text { quality assurance services } \\
\text { - RR2: Financial services \& products. }\end{array}$ & $\begin{array}{l}\text { Coordination \& governance } \\
\text { - CG1: Sector governance \& } \\
\text { coordination } \\
\text { - CG2: Seed information } \\
\text { - CG3: Seed trade association } \\
\text { - CG4: Alignment of donor } \\
\text { interventions. }\end{array}$ & $\begin{array}{l}\text { Regulation \& management } \\
\text { - RM1: Plant variety protection } \\
\text { - RM2: Variety release } \\
\text { - RM3: Seed import } \\
\text { - RM4: Seed export. }\end{array}$ \\
\hline
\end{tabular}




\subsection{Development partners and SIPs}

During the seed sector assessment, the consultancy team interacted with the FMARD's development partners. They were consulted on their engagement in specific SIPs, the outcome of the consultation is presented in Table 5. Individual SIPs are presented with a maximum of five steps or activity groups. Development partners are currently supporting and financing specific steps or parts of such steps within selected SIPs. For example, the Alliance for a Green Revolution in Africa (AGRA) with funding from the United States Agency for International Development (USAID), is financing step one of the SIP for tackling counterfeit seed, i.e. designing, piloting and scaling traceability innovations using information and communication technology (ICT). Note that interventions may be restricted to certain crops or states. The NSRM with its SIPs and the overview of development partner involvement provides options for future investments of development partners, ensuring demand orientation and alignment and avoiding duplication. An example of such a design option is where a number of SIPs or parts of them inspire and inform the proposal development for a four-year programme for the NigeriaNetherlands Seed Partnership.

Table 5 Development partners and their engagement in SIPs structured along the six functions of seed sector transformation

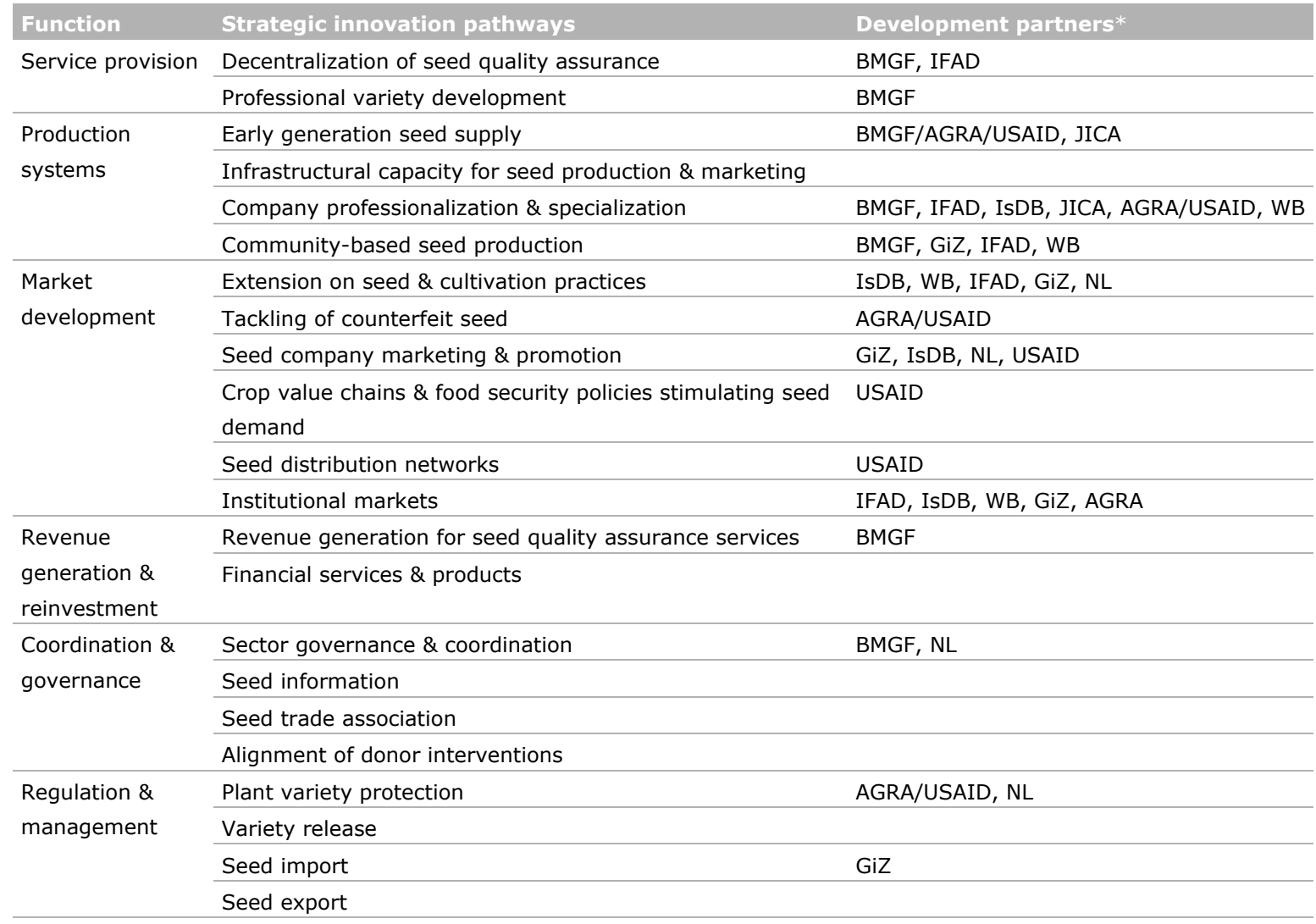

* Acronyms: AGRA: Alliance for Green Revolution in Africa; BMGF: Bill \& Melinda Gates Foundation; GiZ: German Corporation for International Cooperation; IFAD: International Fund for Agricultural Development; IsDB: Islamic Development Bank; JICA: Japan International Cooperation Agency; NL: Netherlands international development cooperation through various modalities; USAID: United States Agency for International Development; WB: World Bank 


\subsection{Service provision}

\section{Decentralization of seed quality assurance (SIP-SP1)}

Ambition Consolidated, effective and sustainable seed quality assurance systems cover multiple crops (cereals, legumes, RTBs, and vegetables) and provide services to different types of seed entrepreneurs (service provision). Specific seed quality assurance standards and protocols developed and implemented for all crops, especially for RTBs and vegetables (regulation \& management).

Challenge The NASC's human, technical, and operational capacity, including the available seed laboratories and vehicles in regional offices, are not yet fully equipped in accordance with the International Seed Testing Association (ISTA) nor able to cope with the industry's demand. Therefore, the NASC is unable to meet the national and diverse demand for seed quality assurance services by seed companies, seed producers, community-based seed production (CBSP) schemes and local seed entrepreneurs. The NASC primarily focuses on a few major cereal crops. Seed quality standards and protocols have not yet been developed for all crops; for those that have been developed, their implementation is limited. Standards, protocols, and the use of digital applications, including the Seed Tracker (IITA, 2020a) and Seed-Codex (AgroNigeria, 2019), are required to increase the effectiveness and efficiency of seed quality assurance systems. Stakeholders, particularly those within intermediary and informal seed systems engaging in seed production of crops of interest to the nation's food and nutrition security, other than the major cereals, are hampered in accessing seed quality assurance services and are unable to produce and market certified seed.

Strategic 1. Review the NASC's existing operational approach to accreditation and third-party field inspection, innovation seed testing and quality control, and seed certification; assess the opportunities for fostering pathway decentralization and the inclusion of multiple crops within the NASC Act; assess the NASC's crop coverage in terms of standards, protocols and quality assurance modalities.

2. Assess linkages between seed entrepreneurs in multiple seed systems and the NASC for seed quality assurance services and crop coverage; assess the diversity of arrangements and modalities for thirdparty inspection by private seed certification entities, and accreditation of seed entrepreneurs for internal quality control; assess standards and protocols available for crops not covered in Nigeria but available elsewhere.

3. Pilot and promote the use of digital solutions such as Seed Tracker and Seed-Codex technologies within decentralized seed quality assurance modalities.

4. Pilot decentralized seed quality assurance modalities within major value chain development programmes; support tailored seed technology and systems-oriented human capacity; develop and test standards, protocols and modalities for crops not yet covered.

5. Monitor progress and impact of pilots, facilitate learning lessons, foster scaling and institutionalization.

Stakeholders - NASC

- Seed entrepreneurs, including companies, producers, farmer seed producers and their associations engaged in CBSP

- Value chain and private sector development programmes, including seed components.

Catalyst Consulting company or NGO with knowledge of the seed sector, including a strong business profile; ICT company with ability to support the adaptation and use of Seed Tracker and Seed-Codex technologies.

Policy Article 39 of the NASC Act (2019) states that seed of registered varieties from the informal sector, if reference commercialized, is subject to quality control procedures, and article 15 supports decentralized (thirdparty) seed quality assurance. The NASC Strategy (2020-2024) elaborates a strategy and plan to outsource seed certification to third-party stakeholders, through private seed certification entities and through a system of accreditation. It further provides guidelines for promoting the use of Seed Tracker technology to increase efficiency.

Proposed five- Decentralized systems and modalities for seed quality assurance supported by Seed Tracker and Seedyear horizon Codex technologies have been piloted and tested in at least five crops, covering multiple seed systems and at least five states; lessons learned on modalities, ICT technologies, standards and protocols are available and incorporated in a plan for further scaling and institutionalization.

Proposed ten- Decentralized systems and modalities for seed quality assurance are mainstream, which results in year horizon certified seed being available for a wide diversity of crops; various seed quality assurance modalities are used by seed entrepreneurs; the NASC oversees the larger seed quality assurance structure, which is effective and efficient. 
- The Seed Control and Certification Institute (SCCI) in Zambia is responsible for the regulation of the seed sector; its services are well coordinated and automated, thereby ensuring that quality seed is delivered to buyers. Private sector inspectors and laboratories are accredited and engaged directly by seed companies and other entrepreneurs to conduct seed quality assurance services in a manner tailored to specific seed systems; the SCCI audits private testing laboratories and private seed inspectors.

- The project 'Building an Economically Sustainable Integrated Seed System for Cassava for Nigeria' (BASICS) (RTB-CGIAR, 2020a) establishes and supports a network of geographically distributed, community-based village seed entrepreneurs, including decentralized forms of seed quality assurance.

- IFAD's Integrated Value Chain Project in Nigeria engages in third-party inspection of seed produced by local rice seed producers in various states (IFAD, 2020).

- Wageningen University \& Research (WUR) seed projects in Myanmar have supported government partners to develop a digital application system and seed portal that facilitate seed quality assurance (WUR, 2020a).

- The Integrated Seed Sector Development project in Uganda has developed a decentralized system of quality declared seed (QDS), and modalities involving third-party seed quality assurance services (WUR, 2020b).

\section{Professional variety development (SIP-SP2)}

\begin{tabular}{|c|c|}
\hline Ambition & $\begin{array}{l}\text { Enhanced public capacity for variety development with functional research, farmer and market linkages } \\
\text { (service provision). }\end{array}$ \\
\hline Challenge & $\begin{array}{l}\text { The public capacity for variety development of crops of importance for food and nutrition security, where } \\
\text { private sector investment is currently not profitable, is limited in Nigeria. Few breeders cover crops that } \\
\text { are vital for food security and agricultural development. The capacity of breeders and their programmes is } \\
\text { limited, because their budgets are restricted and unreliable; their infrastructure and facilities are hindered } \\
\text { from operating professionally and in line with their national responsibilities. Until NARIs have sufficient, } \\
\text { secure and sustainable budget allocations for variety development, they will remain dependent on } \\
\text { externally funded projects and will thus continue to be donor driven. If such circumstances continue, } \\
\text { NARIs will continue to be perceived as low-paid testing and labour partners of CGIAR crop development } \\
\text { programmes. To a limited degree, they engage in public-private partnerships with seed companies and } \\
\text { other seed entrepreneurs, which may foster their business and variety promotion. There are no } \\
\text { mechanisms in place for partial cost recovery for research through PVP or other instruments. The national } \\
\text { capacity for crop development for critical food crops continues to be dependent on CGIAR, supported by a } \\
\text { few international development and philanthropic organizations. }\end{array}$ \\
\hline \multirow[t]{4}{*}{$\begin{array}{l}\text { Strategic } \\
\text { innovation } \\
\text { pathway }\end{array}$} & $\begin{array}{l}\text { 1. Assess national breeding programmes using the Breeding Program Assessment Tool (BPAT) (UQ, } \\
\text { 2020); design and restructure programmes to enhance their efficiency and effectiveness; engage in } \\
\text { human and institutional capacity development in technical, business and management aspects; } \\
\text { invest in infrastructure. }\end{array}$ \\
\hline & $\begin{array}{l}\text { 2. Operationalize and enforce laws and regulations for variety development and the protection of } \\
\text { varieties developed by public and private breeders. }\end{array}$ \\
\hline & $\begin{array}{l}\text { 3. Co-create a space for and pilot public-private partnerships in variety development covering maize, } \\
\text { rice, legumes and RTBs. }\end{array}$ \\
\hline & $\begin{array}{l}\text { 4. Assess public financing and policies required for a more structured and sustainable funding of public } \\
\text { crop improvement programmes, especially for food crops whose seed systems are commercially less } \\
\text { attractive; foster and engage in advocacy for sustainable and reliable public financing for variety } \\
\text { development programmes for food security crops. }\end{array}$ \\
\hline Stakeholders & $\begin{array}{l}\text { - FMARD, Federal Ministry of Finance (FMoF) } \\
\text { - NARIs and universities } \\
\text { - IITA, ICRISAT, AfricaRice, the International Potato Center (CIP) and WorldVeg } \\
\text { - Seed companies, producers and other seed entrepreneurs. }\end{array}$ \\
\hline Catalyst & $\begin{array}{l}\text { University of Queensland through BPAT with regional consultants and/or partnership with CGIAR Centers } \\
\text { in Nigeria that have gone through a BPAT process; consulting firm or knowledge organization with insights } \\
\text { in public financing. }\end{array}$ \\
\hline
\end{tabular}




\begin{tabular}{|c|c|}
\hline $\begin{array}{l}\text { Policy } \\
\text { reference }\end{array}$ & $\begin{array}{l}\text { The APP (2016-2020) in its input section refers to the critical role that public research organizations play } \\
\text { in variety development; with its strong focus on private sector development, the APP does not elaborate } \\
\text { mechanisms to foster the linkage between public organizations and seed entrepreneurs. The NASC Act } \\
(2019) \text {, in article } 38 \text {, indicates that the NASC shall approve of and implement programmes and measures } \\
\text { for promoting genetic improvement of plant varieties and the protection of breeders' rights. }\end{array}$ \\
\hline $\begin{array}{l}\text { Proposed five- } \\
\text { year horizon }\end{array}$ & $\begin{array}{l}\text { The capacities of at least five variety development programmes within NARIs and/or universities have } \\
\text { been improved in human resource, management and infrastructural capacity making use of BPAT. Public- } \\
\text { private partnerships (PPPs) for variety development are operational for maize and RTBs. Fiscal incentive } \\
\text { structures are studied and in a pilot stage of implementation. Opportunities for creating more sustainable } \\
\text { public funding of variety development have been identified and piloted. }\end{array}$ \\
\hline $\begin{array}{l}\text { Proposed ten- } \\
\text { year horizon }\end{array}$ & $\begin{array}{l}\text { NARIs, universities and seed companies gain revenues for variety development and reinvest such } \\
\text { resources; FMARD commits and provides stable and reliable budgets to the programmes. NARIs and } \\
\text { universities benefit through PVP and their dependence on CGIAR is reduced. PPPs in variety development } \\
\text { have become operational for maize, legumes, small grains and RTBs. Fiscal incentive structures } \\
\text { supporting investment in variety development are operational, and various investors are benefiting from } \\
\text { them. }\end{array}$ \\
\hline $\begin{array}{l}\text { Illustrative } \\
\text { examples }\end{array}$ & $\begin{array}{l}\text { The BPAT (UQ, 2020) reviews key technical capacity and management components of plant breeding } \\
\text { programmes. It supports the design of improvements that increase efficiency and result in higher rates of } \\
\text { genetic gain; it is used to enhance CGIAR programmes (CGIAR, 2020), and has also strengthened } \\
\text { national programmes in Ethiopia and India. }\end{array}$ \\
\hline
\end{tabular}

\subsection{Production systems}

\section{Early generation seed supply (SIP-PS1)}

Ambition Enhanced commercial and sustainable public and private capacity, structures and processes for early generation seed (EGS) supply including an operational EGS forecasting system (service provision; production systems; revenue generation \& reinvestment).

Challenge Seed companies and producers depend on public research organizations for effective, regular and sustainable access to quality EGS. This supply is constrained for seed of all food crops, except for foundation seed of OPVs of maize. Major constraints hampering EGS supply are the following: (i) the inadequate infrastructural and technical capacity of public research organizations for EGS production and supply; (ii) the limited technical, infrastructural and professional capacity of seed companies and seed producers, which does not allow them to assume responsibilities for EGS production; (iii) the limited human resource and infrastructural capacity of the NASC, which limits it to perform EGS certification across the nation; (iv) the ineffective and non-transparent processes for EGS supply and linkages between public and private stakeholders; and $(v)$ the absence of an EGS forecasting system critical for planning its supply. A global (BMGF \& USAID, 2015) and national study (Context Network \& Sahel Capital, 2016) on commercial and sustainable EGS supply commissioned by BMGF and USAID provide insights on how to improve the organization and structure of EGS supply with tailored strategies for hybrid maize, major cereals (rice, OPV maize), small grains, legumes, and RTBs.

Strategic 1. Explore and facilitate structures and processes for the division of responsibilities and collaboration innovation between public and private stakeholders in EGS supply for specific crop groups (follow-up to the pathway national study).

2. Engage in advocacy and the development of mechanisms for sustainable public financing and investments in EGS production and supply; conduct follow-up activities to the EGS study with critical stakeholders.

3. Design and support the implementation of specialized business models and/or PPPs, involving critical public and private stakeholders for EGS production and supply, with specialization for maize hybrids and OPVs, other major cereals, small grains, legumes, RTBs and indigenous vegetables, including tailored human capacity development.

4. Assess and support the development of a structure and modalities for EGS forecasting.

5. Support the NASC's capacity to conduct EGS certification, including specific diagnostics.

Stakeholders - FMARD; NASC

- NARIs, universities and CGIAR Centers

- Specialized EGS seed companies

- Seed companies and producers

- Development partners. 
Catalyst Consulting firm with insights into seed sector development, capabilities in the design and facilitation of PPPs and business development, and insights into the structure of public finance in close collaboration with NARIs, the NASC, seed companies and other seed entrepreneurs.

\begin{tabular}{|c|c|}
\hline $\begin{array}{l}\text { Policy } \\
\text { references }\end{array}$ & $\begin{array}{l}\text { The APP (2016-2020) aims to increase the availability of quality seed and prioritizes EGS supply. The } \\
\text { NASC Act (2019) defines classes for seed, including EGS. The NASC strategy (2020-2024) outlines that } \\
\text { the NASC will introduce a diagnostic certification process for ensuring EGS purity. }\end{array}$ \\
\hline $\begin{array}{l}\text { Proposed } 10- \\
\text { year horizon }\end{array}$ & $\begin{array}{l}\text { Seed companies and producers source EGS through a regular, structured and transparent manner from } \\
\text { specialized companies and PPPs; these specialized seed companies and PPPs have gained a specific place } \\
\text { in the market and are financially sustainable; dedicated and sustainable public financing arrangements } \\
\text { cover public components of those PPPs; an EGS forecasting system covers all crops. }\end{array}$ \\
\hline
\end{tabular}

\section{Infrastructural capacity for seed production \& marketing (SIP-PS2)}

\begin{tabular}{|c|c|}
\hline Ambition & $\begin{array}{l}\text { Enhanced infrastructural capacity for the production, processing, storing and marketing of quality seed, } \\
\text { including early generation seed (EGS), driven by individual and specific crops or crop groups (e.g. RTBs, } \\
\text { legumes and/or others) among seed companies and other seed entrepreneurs, including public research } \\
\text { organizations engaged in PPPs for EGS supply (production systems; market development; service } \\
\text { provision). }\end{array}$ \\
\hline Challenge & $\begin{array}{l}\text { Seed companies, seed producers and other seed entrepreneurs are constrained by poor infrastructural } \\
\text { capacity, particularly in terms of seed processing and storage for crops like legumes and RTBs. This also } \\
\text { applies to public research organizations responsible for EGS supply of crops, such as RTBs, requiring } \\
\text { specific production capacity. Entrepreneurs and such organizations need to invest in nurseries, tissue } \\
\text { culture laboratories or other rapid multiplication technologies. Currently, they leverage facilities owned by } \\
\text { international research centres like IITA and this trend is expected to continue in the future. Seed } \\
\text { entrepreneurs have no other choice than to maintain a short-term business perspective; they save and } \\
\text { invest financial resources to a limited degree only. A number of factors explain this business behaviour } \\
\text { and are a reflection that they operate in an immature sector. Problems include the mixed messages that } \\
\text { farmers get through donor-funded and government-driven giveaway programmes and campaigns, which } \\
\text { tend to reduce the reference value of quality seed and associated insecurity in terms of an enabling } \\
\text { environment for the seed market. These factors thus reduce the ability and willingness of entrepreneurs } \\
\text { to invest in the infrastructural capacity (especially storage) required for further professionalization, with } \\
\text { impact on the quality, quantity and diversity of available seed. Moreover, they invest only to a limited } \\
\text { degree in seed marketing and promotion, which further reduces uptake by farmers. }\end{array}$ \\
\hline $\begin{array}{l}\text { Strategic } \\
\text { innovation } \\
\text { pathway }\end{array}$ & $\begin{array}{l}\text { 1. Assess in the context of individual crops and crop groups, the current capacity of seed companies } \\
\text { and other seed entrepreneurs, in infrastructure (buildings, storage, processing and other equipment) } \\
\text { for production and marketing; assess the current business plans, operations, financial resources and } \\
\text { access to finance for investment; included in the assessment are NARIs engaged in PPPs for EGS } \\
\text { supply. }\end{array}$ \\
\hline
\end{tabular}


4. Facilitate matchmaking between seed entrepreneurs and PPPs, with potential organizations providing financial support; provide technical and financial services to seed entrepreneurs and PPPs to enhance their eligibility for support.

5. Monitor the progress and impact of support, facilitate lessons learned and foster scaling.

\begin{tabular}{|c|c|}
\hline ake & $\begin{array}{l}\text { - Seed companies, seed producers and other seed entrepreneurs } \\
\text { - Public research organizations that are part of PPPs engaged in EGS supply } \\
\text { - Value chain development and private sector development programmes } \\
\text { - Commercial financial service providers and banks operating in the agricultural sector } \\
\text { - International development banks including the African Development Bank (AFDB), IsDB, World Bank or } \\
\text { programmes such as the Africa Enterprise Challenge Fund (AECF). }\end{array}$ \\
\hline Catalyst & $\begin{array}{l}\text { Consulting company or NGO with knowledge of the seed sector, including a strong business profile, with } \\
\text { insights into financing an upgrade of the infrastructural capacity of seed entrepreneurs, and insights into } \\
\text { the world of agricultural finance. }\end{array}$ \\
\hline $\begin{array}{l}\text { Policy } \\
\text { reference }\end{array}$ & nolicy $r$ \\
\hline $\begin{array}{l}\text { Proposed two- } \\
\text { year horizon }\end{array}$ & $\begin{array}{l}\text { An assessment of the capacity of the seed production and marketing infrastructure of a diversity of seed } \\
\text { entrepreneurs is available, including companies, producers and other local entrepreneurs, and public } \\
\text { organizations engaged in PPPs for EGS supply. The entrepreneurs and PPPs included operate in at least } \\
\text { five states and are engaged in the production and marketing of quality seed and/or EGS of cereals, } \\
\text { legumes, RTBs and/or vegetables. An overview of the opportunities for financial support and/or finance } \\
\text { for upgrading infrastructural capacity, is available, and it includes eligibility criteria for obtaining such } \\
\text { support. }\end{array}$ \\
\hline $\begin{array}{l}\text { Proposed five- } \\
\text { year horizon }\end{array}$ & $\begin{array}{l}\text { Seed entrepreneurs and PPPs for EGS supply covering multiple crops have upgraded their infrastructural } \\
\text { capacity for production and marketing of quality seed and EGS; enhanced their professionalization, mid- } \\
\text { term business perspective and degree of specialization; and use, as part of their business model us } \\
\text { financial products and services in upgrading and maintaining their infrastructure. }\end{array}$ \\
\hline $\begin{array}{l}\text { Illustrative } \\
\text { examples }\end{array}$ & $\begin{array}{l}\text { - AGRA's Program for African Seed Systems (PASS) has supported seed companies and agro-dealers in } \\
\text { their capacity to market quality seed in several African countries (AGRA, 2017). } \\
\text { - BASICS (RTB-CGIAR, 2020c) and YIFSWA (IITA, 2020c) facilitate establishment of and support seed } \\
\text { entrepreneurs who respectively produce and sell certified stems of market-preferred improved cassava } \\
\text { varieties and engage in a pilot-setting in the production and marketing of seed yam; they provide some } \\
\text { support, enhancing the infrastructural capacity required for these crops. } \\
\text { - TLIII works with seed companies and seed entrepreneurs to produce and market quality seed of } \\
\text { different classes of legumes preferred by farmers (ICRISAT, 2020b). }\end{array}$ \\
\hline
\end{tabular}

\section{Company professionalization \& specialization (SIP-PS3)}

$\begin{array}{ll}\text { Ambition } & \text { Increased professionalization and specialization of seed companies and other seed entrepreneurs in the } \\ & \text { production and marketing of seed of specific crops or crop groups (production systems; market } \\ & \text { development; service provision). } \\ \text { Challenge } & \text { Nigerian seed companies have a wide portfolio of crops for which they produce, procure and market seed. } \\ & \text { A seed company's engagement in specific crops is oftentimes encouraged by institutional markets, } \\ & \text { through which government, NGOs and projects purchase seed in large quantities. This, coupled with the } \\ & \text { insecure business environment, causes the primary business model to remain short- rather than mid- or } \\ & \text { long-term focused, while also to a limited degree invest in highly capable human resources. For the } \\ & \text { industry and sector to mature, seed companies need to become professional in the production and } \\ & \text { marketing of quality seed. Instead of following singular opportunities in their crop portfolio, they need to } \\ & \text { specialize in a limited crop portfolio. For example, seed business of RTBs (e.g. yam, cassava and potato) } \\ & \text { requires specialized capacities in the production of quality EGS, specific processing and storage } \\ & \text { infrastructure, and development of specialized marketing networks. Another example is for companies } \\ & \text { that market vegetable seed: they procure seed from internationally operating seed companies. However, } \\ & \text { they lack dedication and professionalism in their practices in identifying varieties, (re-) packaging, } \\ & \text { promotion and marketing; these are all practices required to boost seed business in the horticultural } \\ & \text { sector. }\end{array}$

Strategic

innovation pathway
1. Assess the capacity of seed companies with a perspective of further professionalization and specialization and the market potential for quality seed for various crops.

2. Explore the viability, business modalities and institutional positioning for business support services that promote seed company professionalization and specialization.

3. Based on the assessments, establish and promote business support service entities that engage in capacity development in technical and business aspects, facilitate business linkages and planning, as 
well as provide coaching on production, marketing and financial management of seed companies, with a focus on specific crops and markets (e.g. RTBs - cassava, yam and/or potato; legumes and/or vegetables).

4. Monitor the progress and impact of pilots, facilitate lessons learned and foster scaling.

5. Support SEEDAN and/or other organizations to facilitate the piloted types of services for specialization in a structured and commercial manner.

\author{
Stakeholders - Seed companies \\ - NARIs and universities, CGIAR Centers \\ - SEEDAN \\ - Business support services.
}

Catalyst Consulting firm or services provider with strong profile in business development and the seed sector. Policy Neither the APP (2016-2020) nor the NASC strategy (2020-2024) provide policy references for reference professionalization and specialization of seed companies.

Proposed five- A network of at least three business support service entities supports seed companies covering three year horizon regions of the country; while still being subsidized, their business is becoming commercially viable and autonomous. For individual or combinations of crops that include RTBs (cassava, yam and/or potato) or vegetables, at least ten seed companies have specialized, they cover at least three states per crop/crop group.

Illustrative - AGRA-PASS has provided significant support to seed companies in their capacity to produce and market examples quality seed in several African countries (AGRA, 2017).

- BASICS supports multiple business models in cassava seed production and marketing; it assists seed entrepreneurs to specialize and make a business in cassava seed production (RTB-CGIAR, 2020a).

\title{
Community-based seed production (SIP-PS4)
}

\begin{tabular}{|c|c|}
\hline Ambition & $\begin{array}{l}\text { Strengthened community-based seed production (CBSP) schemes and local seed entrepreneurs contribute } \\
\text { to the increased availability of quality seed of major cereals (except maize), legumes, small grains and } \\
\text { RTBs, accessible to farmers; they have evolved into business-oriented, legitimate, legal, institutionally } \\
\text { supported and organized, trustworthy and sustainable stakeholders in the production and marketing of } \\
\text { quality seed of improved varieties (production systems; market development); CBSP schemes and local } \\
\text { seed entrepreneurs have structural linkages with public research organizations for access to new } \\
\text { improved varieties, EGS and other technologies; they are also linked to the NASC, using decentralized } \\
\text { modalities for seed quality assurance and with financial organizations, enhancing their business } \\
\text { orientation, available financial resources and sustainability (service provision). }\end{array}$ \\
\hline Challenge & $\begin{array}{l}\text { The fact that quality seed of new improved varieties for major cereals (except maize), legumes, small } \\
\text { grains and RTBs is not readily available to farmers limits variety replacement and opportunities to } \\
\text { increase productivity for those crops. Moreover, farmers do not get the chance to compare improved } \\
\text { varieties in fields similar to their own; they are hesitant to risk trying them. The low profitability of seed } \\
\text { business for those crops limits the investment from seed companies in their production, promotion and } \\
\text { marketing, unless triggered by institutional markets or by a strong demand from value chain actors like } \\
\text { aggregators and processors. Variety development is the responsibility of public research organizations. } \\
\text { CBSP schemes and local seed entrepreneurs depend on structural linkages with public organizations } \\
\text { engaged in variety development and seed quality assurance; currently, such linkages are project } \\
\text { dependent. They often operate without a legal and regulatory status, which further jeopardizes their } \\
\text { linkages and operations, as well as restricts their access to financial products and services to further } \\
\text { develop as a business and ensure their sustainability. }\end{array}$ \\
\hline \multirow[t]{2}{*}{$\begin{array}{l}\text { Strategic } \\
\text { innovation } \\
\text { pathway }\end{array}$} & $\begin{array}{l}\text { 1. Assess current CBSP, local and informal seed production systems for linkages with organizations } \\
\text { engaged in variety development and seed quality assurance; assess the legal and regulatory } \\
\text { requirements for seed producers and entrepreneurs; assess their access to and availability of tailored } \\
\text { financial products and services; assess farmers' willingness to pay for quality seed produced and } \\
\text { marketed for those crops. }\end{array}$ \\
\hline & 3. Monitor the progress and impact of pilots, facilitate learning lessons, and foster scaling. \\
\hline
\end{tabular}


4. Bring together local seed entrepreneurs and CBSP organizations in a new association or subchapter of an existing association (e.g. SEEDAN), which hosts a unit that provides services in a commercial and thereby sustainable manner.

\begin{tabular}{|c|c|}
\hline ers & $\begin{array}{l}\text { - Community-based seed producers, local seed entrepreneurs and their associations } \\
\text { - NARIs, universities and CGIAR Centers } \\
\text { - NASC, SEEDAN and/or farmers' associations } \\
\text { - Value chain development programmes, including CBSP and local seed entrepreneurship components. }\end{array}$ \\
\hline Catal & $\begin{array}{l}\text { Consulting company or NGO with knowledge of the seed sector, including a strong business profile and } \\
\text { understanding of informal markets. }\end{array}$ \\
\hline $\begin{array}{l}\text { icy } \\
\text { erence }\end{array}$ & $\begin{array}{l}\text { Article } 39 \text { of the NASC Act (2019) defines that seed from the informal sector of registered varieties, if } \\
\text { commercialized, is subject to quality control procedures; and article } 15 \text { supports decentralized (third } \\
\text { party) seed quality assurance. The NASC strategy (2020-2024) aims to register and issue licenses to } \\
\text { community-based seed entrepreneurs to produce quality seed, and outlines that the NASC engages in } \\
\text { local entrepreneur training. }\end{array}$ \\
\hline $\begin{array}{l}\text { Proposed five- } \\
\text { year horizon }\end{array}$ & $\begin{array}{l}\text { Seed producers engaged in CBSP and local seed entrepreneurs have stronger and more structural } \\
\text { linkages with research organizations for accessing new varieties and EGS. These seed producers and } \\
\text { entrepreneurs have a clear legal and regulatory status, which ensures their access to various services and } \\
\text { creates opportunities for accessing tailored finance. They are organized in a specific association or } \\
\text { subchapter of an existing association that hosts the service provision unit. Decentralized seed quality } \\
\text { assurance is well-functioning and financially viable. }\end{array}$ \\
\hline $\begin{array}{l}\text { Proposed ten- } \\
\text { year horizon }\end{array}$ & $\begin{array}{l}\text { The use of quality seed of improved varieties for the crops produced and marketed by farmers engaged in } \\
\text { CBSP, and by local seed entrepreneurs, has increased significantly. These entrepreneurs have coalesced } \\
\text { into commercial and sustainable networks to enjoy the benefits of scale and association. They are a } \\
\text { critical part of the seed sector and have structural linkages with research, seed quality assurance and } \\
\text { financial organizations. They are organized in a subchapter of an existing or new association, which } \\
\text { facilitates their linkages with critical stakeholders, and provides commercial services in business } \\
\text { development. }\end{array}$ \\
\hline $\begin{array}{l}\text { Illus } \\
\text { exan }\end{array}$ & $\begin{array}{l}\text { - BASICS established and supported a network of geographically distributed, village seed entrepreneurs } \\
\text { (or CBSPs) who produce and sell certified stems of market-preferred improved cassava varieties (RTB- } \\
\text { CGIAR, 2020c). } \\
\text { - Both ISSD Ethiopia (WUR, 2020c) and ISSD Uganda (WUR, 2020d) have been successful in establishing } \\
\text { local seed business, and supporting their linkages with research and quality assurance organizations on } \\
\text { a structural basis. }\end{array}$ \\
\hline
\end{tabular}

\subsection{Market development}

\section{Extension on seed \& cultivation practices (SIP-MD1)}

\begin{tabular}{|c|c|}
\hline Ambition & $\begin{array}{l}\text { Enhanced public and private extension services that promote farmers' use of quality seed of improved } \\
\text { varieties combined with advanced cultivation practices (market development; service provision). }\end{array}$ \\
\hline Challenge & $\begin{array}{l}\text { Increasing crop productivity and closing the yield gap for all crops in Nigeria requires a combination of } \\
\text { quality seed of improved varieties and advanced cultivation practices. If both interventions are not } \\
\text { utilized, farmers may not be able to earn back their investment in quality seed. Current low extension } \\
\text { agent-to-farmer ratios, combined with limited involvement of seed companies and other seed } \\
\text { entrepreneurs in extension support, constrain farmers' access to knowledge and information on quality } \\
\text { seed and advanced cultivation practices that suit their agro-ecology and farming systems. Moreover, } \\
\text { public extension workers lack the skills for promoting quality seed of new and improved varieties for } \\
\text { distinct crops and advanced cropping practices. For example, they have limited knowledge and expertise } \\
\text { in RTBs and horticulture, which in cases when inappropriate advice is given aggregates the problem. }\end{array}$ \\
\hline \multirow[t]{2}{*}{$\begin{array}{l}\text { Strategic } \\
\text { innovation } \\
\text { pathway }\end{array}$} & $\begin{array}{l}\text { 1. Design and pilot a facility that supports public and private extension organizations in training and } \\
\text { demonstration, including tailored (seed technology and business oriented) human capacity } \\
\text { development; where appropriate, link the services with major donor-funded private sector } \\
\text { development and value chain programmes. }\end{array}$ \\
\hline & $\begin{array}{l}\text { 2. Through the facility, support at scale development of the human and technical capacity of public and } \\
\text { private extension organizations on the benefits of quality seed and improved varieties, the sources } \\
\text { of quality seed, and the use of advanced cultivation practices; promote the use of modalities such as } \\
\text { variety and seed quality demonstrations, farmers' field days, and large-scale awareness campaigns } \\
\text { (e.g. radio shows and fairs). }\end{array}$ \\
\hline
\end{tabular}


3. Support universities and research in the design and implementation of action research, proving the benefits of using quality seed of improved varieties and improved cultivation.

4. Establish a pathway for communication between primarily domestic research and extension organizations, if appropriate linked to the facility, on the use of quality seed of improved varieties and advanced cultivation practices.

5. Develop a knowledge management system, if appropriate, linked to the facility, supporting extensionists and trainers with e-learning modules and quality promotion materials.

\begin{tabular}{|c|c|}
\hline akeholders & $\begin{array}{l}\text { - National Agricultural Extension and Research Liaison Services (NAERLS), Training-of-trainer units and } \\
\text { Agricultural Development Programmes (ADPs) } \\
\text { - NARIs } \\
\text { - Private extension outfits; seed companies and other seed entrepreneurs } \\
\text { - NGOs } \\
\text { - Farmers. }\end{array}$ \\
\hline Catalyst & $\begin{array}{l}\text { NAERLS, based at Ahmadu Bello University (ABU), in collaboration with an NGO or consulting firm with } \\
\text { strong communication and institutional development skills. }\end{array}$ \\
\hline Policy reference & $\begin{array}{l}\text { The APP (2016-2020) highlights the importance of access to information and knowledge for all } \\
\text { stakeholders, including farmers, to improve agricultural productivity. It mentions the development of a } \\
\text { new strategy for promoting demand-driven and pluralistic extension services, involving public and } \\
\text { qualified NGO and private sector players, closely linked to research. }\end{array}$ \\
\hline $\begin{array}{l}\text { Proposed two- } \\
\text { year horizon }\end{array}$ & $\begin{array}{l}\text { The facility for support to public and private extension, and the promotion of quality seed and advanced } \\
\text { cultivation practices for RTBs, vegetables and other crops, is tested and operational in at least five states } \\
\text { in collaboration with private sector and value chain development programmes that are supported by } \\
\text { donors and development partners. }\end{array}$ \\
\hline $\begin{array}{l}\text { Proposed five- } \\
\text { year horizon }\end{array}$ & $\begin{array}{l}\text { Public and private extension has knowledge on quality seed, improved varieties and advanced cultivation } \\
\text { practices targeting specific crops (e.g. RTBs, vegetables), and use more effective communication tools in } \\
\text { more than ten states of the country; the facility supports them in a structural manner; its services are } \\
\text { sustainable, facilitating linkages with research as well allowing for knowledge management; extension is } \\
\text { reaching scale through major private sector and value chain programmes. }\end{array}$ \\
\hline $\begin{array}{l}\text { Illustrative } \\
\text { examples }\end{array}$ & $\begin{array}{l}\text { - ISSD Uganda vegetable component: training of sector professionals; establishment of a network of } \\
\text { trained agronomists for knowledge exchange; a facility for variety demonstrations; and farmer } \\
\text { extension services by third parties and companies (WUR, 2020e). } \\
\text { - SEVIA Tanzania: campaigning for advanced varieties and high-quality vegetable seeds, combined with } \\
\text { improved nursery, crop nutrition, crop protection and crop cultivation techniques adapted to } \\
\text { smallholder farms (SEVIA, 2020). }\end{array}$ \\
\hline
\end{tabular}

\section{Tackling of counterfeit seed (SIP-MD2)}

\begin{tabular}{|c|c|}
\hline Ambition & $\begin{array}{l}\text { Increased enforcement of quality assurance and penalties for counterfeit seed marketing (regulation \& } \\
\text { management); reduced engagement in the marketing of fake seed by seed companies and agro-dealers; } \\
\text { reduced profitability of counterfeiting and thereby reduced viability of non-genuine seed companies and } \\
\text { agro-dealers (production systems); increased farmers' trust in seed companies and agro-dealers } \\
\text { (market development). }\end{array}$ \\
\hline Challenge & $\begin{array}{l}\text { Counterfeit or fake seed is currently widely available in the market; increasingly, farmers consider } \\
\text { purchasing seed a risky proposition, which jeopardizes the development of the entire industry. } \\
\text { Disincentives to counterfeiting have not been working. Penalties have only recently been increased but } \\
\text { require enforcement. Non-genuine seed companies and agro-dealers continue their practices given that } \\
\text { marketing counterfeit seed, despite the risk of penalties, is highly profitable. Institutional markets } \\
\text { (government, NGOs and projects) continue to be a major source of revenues for seed companies; } \\
\text { together, they account for almost } 50 \% \text { of the maize and rice seed market (TASAI, 2019). Packing and } \\
\text { labelling practices in those markets favour the delivery of counterfeit or substandard quality seed, } \\
\text { especially when institutional players procure bulk quantities of seed that are subsequently repacked. } \\
\text { Consequently, delivering substandard quantity seed does not put seed companies' reputation at risk. The } \\
\text { illegal entrance of seed into the country further jeopardizes the trust in the industry. }\end{array}$ \\
\hline $\begin{array}{l}\text { Strategic } \\
\text { innovation }\end{array}$ & $\begin{array}{l}\text { 1. Design, pilot and scale traceability innovations using ICT (ongoing pilot in collaboration with the } \\
\text { NASC, AGRA and MPedigree). }\end{array}$ \\
\hline pathway & $\begin{array}{l}\text { 2. Support the enforcement of penalties and sanctions through short-term training of regulators and } \\
\text { inspectors; support enforcement of the NASC and the legal system in these functions; support } \\
\text { SEEDAN and the NASC in the set-up of a qualification system for genuine seed companies and in } \\
\text { disqualifying non-genuine companies. }\end{array}$ \\
\hline
\end{tabular}


3. Enhance the standardization of packaging in a public-private partnership through a process of assessment, piloting and scaling.

4. Target changes in the business behaviour of seed companies, market associations, agro-dealers and farmer associations; and create awareness among farmers on identifying and purchasing quality seed.

5. Design and pilot mechanisms and guidelines for the procurement of seed by institutional players that favour quality seed and restrict opportunities for counterfeit or substandard quality seed marketing.

Stakeholders - FMARD, legal system, NASC, NAQS, Nigeria Customs and other law enforcement agencies

- SEEDAN, seed companies, market associations, agro-dealers

- ICT providers (e.g. MPedigree) and packaging industry

- Extension officers, NGOs and farmers

- Institutional market players (government, NGOs and projects).

Catalyst Consultancy firm with insights into seed business, seed laws and regulations and ICT technology, in close collaboration with NASC and SEEDAN.

Policy reference The APP (2016-2020) refers in its input section to the delivery of sub-standard or counterfeit inputs; it does not highlight actions to tackle this problem. The NASC Act (2019), section IX, addresses infringement and offences, including increasing penalties. The effectuation depends on the legal system.

Proposed two- The pilot with the tracking system is effective, and the enforcement of penalties and sanctions has year horizon increased; pilots have started among institutional market players to change their procurement practices; a register of trustworthy companies eligible to bid for seed tenders is in place; packaging practices in institutional markets have changed.

Proposed five- Various measures are common practice and have reduced the presence and profitability of counterfeiting year horizon companies and agro-dealers; awareness among farmers and other stakeholders on the value of quality seed is common; counterfeiting has changed from being a structural problem, into a problem that is sporadic and appears in isolated cases.

Illustrative - The NASC collaborates with MPedigree, USAID and AGRA in the use of the SeedCodex tracking app to examples check counterfeit seeds (AgroNigeria, 2019).

- The Kenya Plant Health Inspectorate Service (KEPHIS, Kenya) collaborates with MPedigree to enable ICT verification of seed quality (Kariuki, 2017); likewise efforts are implemented in Uganda (Ashour et al., 2015).

\section{Seed company marketing \& promotion (SIP-MD3)}

Ambitions Increased and more structural investment by seed companies in the marketing and promotion of quality seed and improved varieties that results in an increased awareness of farmers and enhanced willingness to pay for quality seed and improved varieties (market development).

Challenge Quality seed and improved varieties are catalysts for raising crop productivity and profitability; they allow farmers to achieve higher yields and incomes. However, rates of adoption of new varieties and seed replacement of farm-saved with quality seed remain low with implications on crop productivity. Farmers have limited awareness of the benefits, and do not always know what varieties best fit their farming system, agro-ecology and market demands. They are not aware of innovations in seed systems like for example of seed yam, cassava stems, seed of hybrid varieties of crops such maize and tomato, but also quality seed of various other cereals, legumes, RTBs and vegetables. To stimulate a demand for quality seed and improved varieties for various crops, seed companies are required to invest in seed marketing and promotion to educate potential farmer clients and create market demand.

Strategic 1. Enhance the human capacity of seed companies in the development of their marketing and innovation promotion strategy.

pathway 2. Support companies in the implementation of marketing and promotion strategies tailored to farmers. These include a wide range of activities, such as: (i) enhancing the company's last-mile distribution capabilities; (ii) supporting the installation of rural points of sale; (iii) promoting seed sales in farmer-friendly pack sizes; (iv) supporting the organization of wide-scale variety and seed quality demonstrations and farmers' field days; ( $v$ ) enhancing seed companies' participation in agricultural trade shows and seed fairs to promote their products; (vi) supporting the installation of rural micro-seed quality demonstration units; and (vii) engaging in the organization of communication campaigns using local radio and printed promotion materials that illustrate the benefits of quality seed and improved varieties, and facilitate the differentiation of quality from counterfeit seed.

Stakeholders - Domestic and international seed companies; SEEDAN

- National research organizations 
- NASC

- Extension and business development services, media

- Agro-dealers, farmer market organizations and farmers.

Catalyst NGO/consulting firm with expertise on seed marketing and promotion.

Policy reference The NASC in its strategic plan (2020-2024) aims to increase the adoption of quality seed of improved varieties by investing in promotion of quality seed through its website, (social) media campaigns and seed fairs, as well as by corrective actions towards the sales of counterfeit or substandard seed.

Proposed two- At least eight domestic and three international seed companies have a strategy for, and engage in the year horizon promotion and marketing of, quality seed; they have implemented an awareness-raising campaign using different communication tools; each of them has started activities in at least four states.

Proposed five- At least 15 domestic seed companies, complemented by at least six international companies, are year horizon implementing their seed marketing and promotion strategy in a structural manner as part of their business strategy; they are also implementing an awareness-raising campaign promoting quality seed use; each company demonstrates varieties and participates in promotional activities in at least ten states.

Illustrative - AGRA-PASS has supported seed companies and agro-dealers in their capacity to market quality seed in examples several African countries (AGRA, 2017).

- The ISSD Uganda programme has implemented a comprehensive awareness-raising campaign promoting the uptake of quality seed from domestic companies, local seed businesses and international seed companies (WUR, 2020e).

- East-West Seed's Knowledge Transfer programme is promoting the use of improved agronomic technologies in several states of Nigeria, through pre-competitive activities; quality seed of improved vegetable varieties is seen as one of many technologies which farmers need to better understand (East-West Seed, 2020).

\section{Crop value chains \& food security policies stimulating seed demand (SIP-MD4)}

\begin{tabular}{|c|c|}
\hline Ambition & $\begin{array}{l}\text { Enhanced food security policies and more stable prices in grain and crop markets increase farmers' } \\
\text { profitability and enable their investment in the production of food crops, thus contributing to increased } \\
\text { use of inputs such as quality seed of improved varieties (market development; regulation \& } \\
\text { management). }\end{array}$ \\
\hline Chall & $\begin{array}{l}\text { Farmers' willingness to invest in quality seed of improved and new varieties, including hybrids, remains } \\
\text { limited. Uncertainties on cereal grain prices (e.g. maize and rice) relate to government interventions, } \\
\text { trade policies (tariffs and quotas), and flip-flopping of incentives that promote import substitution versus } \\
\text { export-led growth. Opening borders to imports in years when prospects of domestic production fail to } \\
\text { meet national demand, results in low prices for producers and grain smuggling in the border states. The } \\
\text { Anchor Borrower's Programme is an example of an intervention of the Central Bank of Nigeria that } \\
\text { promotes and creates a conducive market for specific commodities in certain areas (CBN, 2016). It } \\
\text { encourages farmers to prioritize focus crops, such as rice, over others. As such, government policies and } \\
\text { interventions impact on the predictability of farm-gate prices, especially for major cereals, thereby } \\
\text { influencing farmers' willingness to invest in inputs. This reality reduces seed companies' motivation to } \\
\text { invest in the production of certified seed of new varieties; for example, they would rather keep to the } \\
\text { production and marketing of seed of older OPV maize varieties than of hybrids. Meeting national food } \\
\text { security and driving economic development, as illustrated in other countries going through a process of } \\
\text { agricultural transformation, creates the conditions needed to incentivize farmers to invest in crop } \\
\text { production and thus invest in purchasing quality seed of new varieties. }\end{array}$ \\
\hline $\begin{array}{l}\text { Strategic } \\
\text { innovation } \\
\text { pathway }\end{array}$ & $\begin{array}{l}\text { 1. Conduct a study on the relationship between food security policies, cereal market development and } \\
\text { farmers' willingness to invest in crop inputs including quality seed of improved varieties. } \\
\text { 2. Elaborate scenarios for promoting agricultural transformation, based on country-studies and } \\
\text { experiences, combined with strategies that incentivize or enable farmers' profitable use of inputs, } \\
\text { including quality seed of new, improved varieties. } \\
\text { 3. Engage in advocacy work to inform policy makers on relevant scenarios. }\end{array}$ \\
\hline
\end{tabular}




\begin{tabular}{|c|c|}
\hline Catalyst & $\begin{array}{l}\text { Research group or think tank with a strong profile in policy and economic analysis, in close collaboration } \\
\text { with FMARD, FMoF and CBN. }\end{array}$ \\
\hline olicy reference & $\begin{array}{l}\text { The APP (2016-2020) focuses its instruments on stimulating agricultural production on a sustainable } \\
\text { basis, and stimulating supply and demand for agricultural produce, by facilitating linkages between } \\
\text { producers and off-takers, while stabilizing prices or reducing price volatility for agricultural produce } \\
\text { through market-led price stabilization mechanisms (commodity exchanges, negotiated off-take } \\
\text { agreements, extended farm-gate prices under value chain coordination mechanisms, agricultural } \\
\text { insurance, etc.). }\end{array}$ \\
\hline $\begin{array}{l}\text { Proposed ten- } \\
\text { year horizon }\end{array}$ & $\begin{array}{l}\text { Farmers' willingness to invest in agricultural inputs and technologies, including quality seed of new } \\
\text { varieties, has increased significantly as predictability of farm-gate prices has increased, and their } \\
\text { investment in inputs and thus increased productivity is profitable. Seed companies engage in the } \\
\text { production and marketing of quality seed of new and improved varieties, including hybrid maize. The } \\
\text { changes result from the clear vision of the Federal Government of Nigeria in implementing policies for } \\
\text { enhanced food security, combined with incentivizing and enabling farmers to invest in increasing } \\
\text { productivity. }\end{array}$ \\
\hline $\begin{array}{l}\text { Illustrative } \\
\text { examples }\end{array}$ & $\begin{array}{l}\text { Both the International Food Policy Research Institute (IFPRI, 2020) and the Department of Agricultural, } \\
\text { Food and Resource Economics of Michigan State University (MSU, 2020) have engaged for many years in } \\
\text { studies on the impact of government interventions on food markets in Africa (e.g. Kenya and South } \\
\text { Africa, where the seed sector is thriving) and beyond, including the impact on input markets. They } \\
\text { advise governments and development organizations of the possible scenarios and impacts of potential } \\
\text { interventions on food and input markets. }\end{array}$ \\
\hline
\end{tabular}

\section{Seed distribution networks (SIP-MD5)}

\begin{tabular}{|c|c|}
\hline Ambition & $\begin{array}{l}\text { Enhanced capacity of agro-dealer networks in the marketing of adequate quantities of quality seed of } \\
\text { improved and demanded varieties of multiple crops, at the right time and affordable price (market } \\
\text { development). }\end{array}$ \\
\hline \multirow{4}{*}{$\begin{array}{l}\text { Strategic } \\
\text { innovation } \\
\text { pathway }\end{array}$} & $\begin{array}{l}\text { 1. Assess the current business models and practices of agro-dealers in seed marketing, including seed } \\
\text { quality assurance. }\end{array}$ \\
\hline & $\begin{array}{l}\text { 3. Develop modalities and structures for business development support service units that include } \\
\text { technical, operational and human capacity development, coaching in entrepreneurship, business-to- } \\
\text { business (B2B) facilitation with seed companies and producers, development and facilitation of } \\
\text { financial incentives and set-up of third-party seed quality assurance. }\end{array}$ \\
\hline & $\begin{array}{l}\text { 4. Monitor progress and impact of pilots and facilitate lessons learned with business development } \\
\text { support service units; foster scaling of successful pilots and modalities. }\end{array}$ \\
\hline & $\begin{array}{l}\text { 5. Support SEEDAN to consider agro-dealers to become eligible for membership within a specific } \\
\text { chapter; support SEEDAN and/or other organizations to facilitate the piloted types of units and } \\
\text { modalities on a commercial basis. }\end{array}$ \\
\hline Catalyst & Consulting company or NGO with knowledge of the seed sector including a strong business profile. \\
\hline $\begin{array}{l}\text { Policy } \\
\text { reference }\end{array}$ & $\begin{array}{l}\text { The APP (2016-2020) highlights unreliable agro-dealer networks as a constraint to seed distribution; it } \\
\text { aims at promoting private sector rural market penetration of agro-dealer networks. Article } 33 \text { of the NASC } \\
\text { Act (2019) indicates that the NASC shall approve procedures and requirements for post-certification } \\
\text { control, including seed processing and marketing. It does not indicate that the NASC inspects the quality }\end{array}$ \\
\hline
\end{tabular}


of seed at agro-dealer sales level. The NASC Strategy (2019) states that it will engage with agro-dealers in capacity development and awareness raising on quality seed.

Proposed five- Agro-dealers and their networks have become more professional in increasing farmers' access to quality year horizon seed and providing services. They have stronger and more structural linkages with seed companies for a diversity of crops. The NASC contributes to quality assurance at agro-dealer sales level; it enhances their awareness of seed management practices. SEEDAN has established a specific chapter for this type of seed entrepreneur and has started to provide business support services on a commercial basis. The percentage of quality seed sold through agro-dealers has increased significantly for several crops.

Proposed ten- Ago-dealers are vibrant, covering a larger area of the country; they are a critical and trustworthy part of year horizon the seed sector and have structural linkages with seed companies, extension and quality assurance organizations. The seed gap for most crops has significantly reduced and varieties are replaced regularly with new, more productive and adapted varieties. SEEDAN provides business support and other services to local seed entrepreneurs that include agro-dealers as part of its organizational mandate. The share of quality seed sold through agro-dealers for most crops is more than $50 \%$.

Illustrative - The Agro-dealer Support Programme of PASS trained and certified more than 40,000 private agroexamples dealers across sub-Saharan Africa, as they are the primary conduit of seed, fertilizers, and knowledge of their proper use, for smallholder farmers (AGRA, 2017).

- BASICS is piloting agro-dealers as NASC third-party inspectors and has connected agro-dealers with a group of local cassava seed producers as their centralized sales agency (RTB-CGIAR, 2020).

\section{Institutional markets (SIP-MD6)}

Ambition Increased demand- and market-driven, dynamic and functioning seed sector that operates sustainably with minimal government, NGO and project subsidies and interventions; if interventions are made, they promote accountability and sustainability (market development; production systems; revenue generation \& reinvestment).

Challenge Institutional markets (government, NGOs and development programmes) constitute a major share of the Nigerian seed market. The African Seed Access Index (TASAI, 2019) estimates that institutional markets represent approximately $50 \%$ of the total volume of maize and rice seed transacted in the market. While institutional buyers have the potential to power the growth of the seed industry, they are often a leading cause of market distortion. Both value chain and private sector development programmes engage in the dissemination and marketing of quality seed of maize, rice, soybean, cowpea, cassava, potatoes and vegetables. Humanitarian and food security programmes purchase and disseminate seed for maize, sorghum, legumes and vegetables. Areas of concern include the size of the demand from institutional markets, the ad-hoc nature of institutional purchases, the inability of institutional buyers to engage in long-term contracts with seed companies, and the practice of procuring seed in bulk. As such, entrepreneurs enter the seed market without the requisite knowledge and skills, a reliable network of seed producers, or common seed business ethics. This reduces the overall functionality of the seed sector as well as the quality of goods and services generated by the industry. With the practice of procuring seed in bulk, institutional players break a critical feature of a healthy seed industry: package integrity. As a result, farmers don't know who produced the seed that they grow, and the reputation of seed companies is no longer at stake when selling seed of a substandard quality. The observation was confirmed during the federal government initiative, Growth Enhancement Scheme (GES). Even though the aspiration is that normal seed markets grow, institutional markets are expected to continue playing an important role in the coming decade. Therefore, institutional players should operate in ways that promote rather than hamper the development of an accountable seed sector, e.g. aligning their interventions with the capabilities, production capacity and planning of genuine seed companies, and engaging in practices promoting sustainable and genuine seed entrepreneurship.

Strategic innovation pathway
1. Assess challenges and opportunities within existing seed procurement, dissemination and marketing practices of large value chain, private sector development, humanitarian and food security programmes.

2. Assess current business models and production capacity of seed companies that supply to institutional markets; assess the current institutional arrangement between institutional players and seed companies.

3. Explore viability, modalities and institutional positioning, and support the operationalization of a service provision unit that coordinates the interface between institutional players and seed companies; provide advisory and technical support services, through the unit, to institutional market players in designing and implementing seed procurement, dissemination and marketing guidelines in a manner that is aligned with the capabilities, production capacity, and multiple-year planning of genuine seed companies; include opportunities for multiple-year contracts. 
4. Strengthen and support the service provision unit to develop seed business-friendly procurement strategies and engage with institutional buyers for their piloting and scaling.

5. Assess the impact of the service provision unit as well as monitor practices used by institutional market players and seed companies; learn lessons on the role and contributions of institutional players promoting seed sector development.

\begin{tabular}{|c|c|}
\hline & $\begin{array}{l}\text { - Government, NGOs and development programmes that procure, disseminate and market seed } \\
\text { - Seed companies } \\
\text { - SEEDAN \& NASC } \\
\text { - Business support services. }\end{array}$ \\
\hline Catalyst & $\begin{array}{l}\text { Independent consulting firm or service provider with a strong profile in business development, risk } \\
\text { assessment and seed sector development, operating in close collaboration with both the NASC and } \\
\text { SEEDAN, either of which could host the service provision unit. }\end{array}$ \\
\hline $\begin{array}{l}\text { Policy } \\
\text { reference }\end{array}$ & $\begin{array}{l}\text { The APP (2016-2020) refers to attempts of previous governments to improve the use of inputs through } \\
\text { subsidy programmes (e.g. GES) and halt the use and delivery of sub-standard or counterfeit inputs. The } \\
\text { NASC strategy (2020-2024) does not address the topic of institutional markets and its impact on the } \\
\text { development of the seed sector. }\end{array}$ \\
\hline $\begin{array}{l}\text { Proposed five- } \\
\text { year horizon }\end{array}$ & $\begin{array}{l}\text { Government agencies, NGOs and projects use practices that are aligned with the production capacity of } \\
\text { genuine seed companies, in the procurement, dissemination and marketing of quality seed, supported by } \\
\text { a qualified and independent service unit; they foster the development of an accountable, professional and } \\
\text { sustainable seed sector. }\end{array}$ \\
\hline $\begin{array}{l}\text { Illustrative } \\
\text { examples }\end{array}$ & $\begin{array}{l}\text { The Private Seed Sector Development Project in Burundi implemented by the International Fertilizer } \\
\text { Development Center (IFDC) has supported the national seed producer's association to partner with } \\
\text { government to engage institutional buyers in the issue of bulk procurement. The association aims to } \\
\text { reduce the impact of large institutional buyers on the market and guide them towards a working } \\
\text { relationship that fosters seed business-friendly procurement strategies. }\end{array}$ \\
\hline
\end{tabular}

\subsection{Revenue generation \& reinvestment}

\section{Revenue generation for seed quality assurance services (SIP-RR1)}

Ambition Enhanced efficiency and effectiveness of the NASC in delivering seed quality assurance services, which are supported by a sustainable mechanism for generating revenues (revenue generation $\&$ reinvestment).

Challenge Seed quality assurance services of the NASC are funded through government budget. There is limited linkage between the NASC's operational budget and the delivery of services such as field inspection, laboratory testing and accreditation of internal seed quality control systems of seed companies and seed producers. The fees paid by seed companies and producers for NASC services do not directly cover the costs of those services but are considered government revenues. Payments from individual seed producers for field inspection and seed lab testing are not feasible. With a growing and more decentralized seed sector, the NASC faces challenges in ensuring efficiency and effectiveness in delivering its services. To improve financial sustainability, Stronger links are needed between the NASC's financial resources and its operations, alongside greater independence from government defined budge.

Strategic 1. Conduct a baseline study on the current revenue system; assess the impact of the current financial innovation model on the implementation of seed quality assurance services, including a cost-benefit analysis; pathway conduct a willingness-to-pay assessment for seed quality assurance services among seed entrepreneurs; assess and learn lessons from revenue-generating mechanisms for seed quality assurance used in other countries (e.g. Kenya, Zambia and South Africa); and explore financing opportunities for reform within the context of the NASC Act (2019) and the larger government structure.

2. Design alternative modalities for financing of seed quality assurance services with the NASC, FMARD, FMoF and representatives of the sector, including the set-up of the NASC Seed Fund, and options for cost reduction; and engage in advocacy to support a pilot.

3. Implement a pilot that operationalizes the NASC Seed Fund, with new financial modalities for payment of seed quality assurance services for a few crops and in a few states.

4. Learn lessons from the pilot, design a mechanism for mainstreaming and create awareness among relevant stakeholders.

5. Arrange for policy support and requirements for institutionalization, and subsequently engage in mainstreaming at scale. 


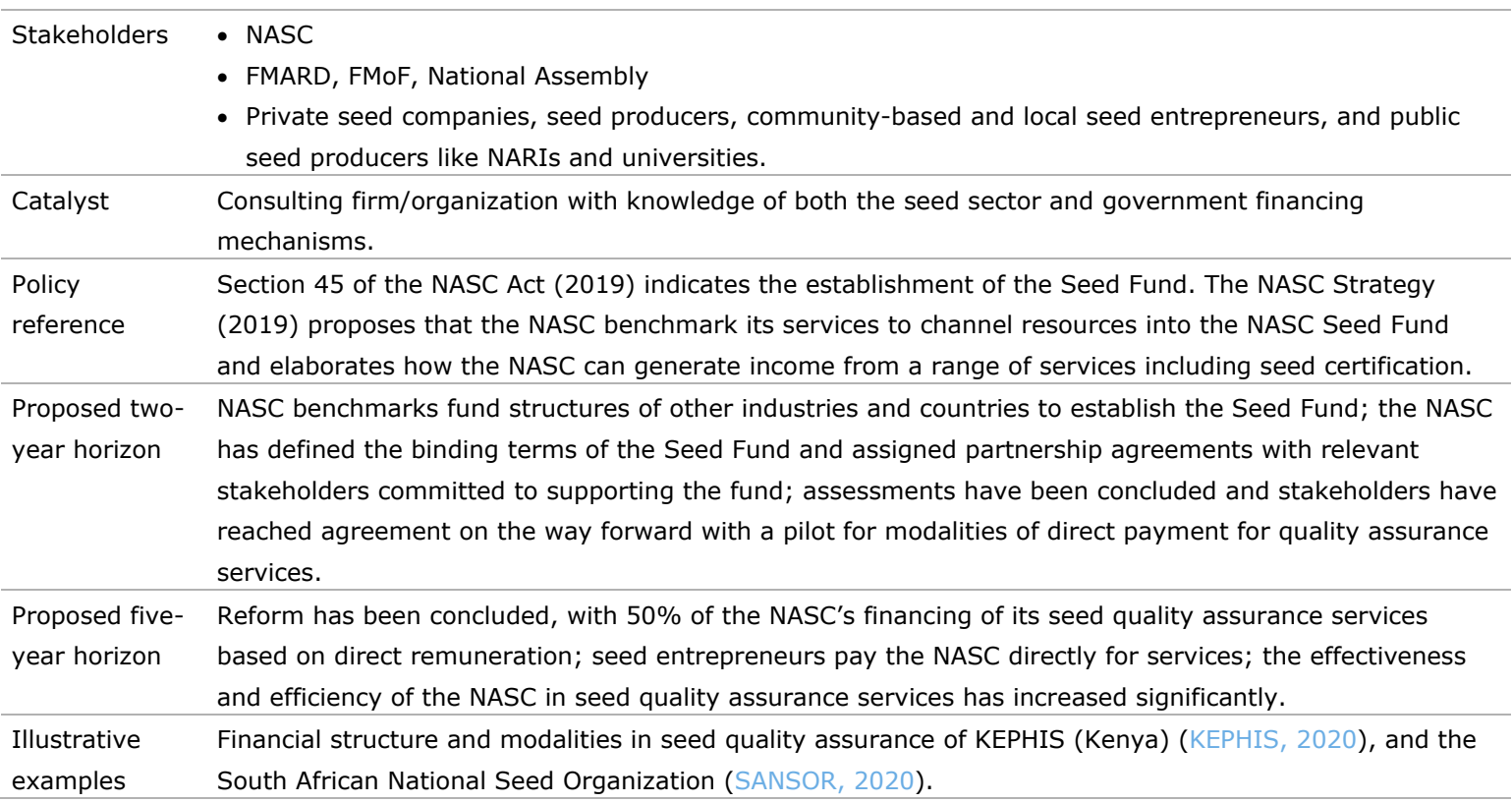

\section{Financial services \& products (SIP-RR2)}

Ambitions Enhanced availability of financial services and products tailored for seed business, and their increased use by seed companies and producers in production and marketing operations (revenue generation \& reinvestment; service provision).

Challenge The agricultural sector has insufficient access to credit, insurance and other financial services and products. Prohibitively high interest rates and loan requirements are unattractive to borrowers; they function as disincentives for agricultural lending. Due to their current business and financial management practices and capabilities, seed companies and other seed entrepreneurs are not eligible for such financing services and products. Moreover, financial institutions and banks, if active in agriculture, neither have knowledge of the seed sector and its specific demands for finance, nor consider its potential. For example, they do not regard seed as collateral for providing credit for seed production or marketing activities. The policy conditions for the agricultural sector through the FMoF or CBN do not address specific subsectors.

Strategic 1. Assess the current market for seed sector tailored finance; assess current formal and informal innovation financial products and services in the sector; assess current and more sector-realistic eligibility pathway criteria; map business models and needs of seed companies and other seed entrepreneurs; assess the seed industry's scope for financial services and products.

2. Engage in capacity building of seed companies and producers in production and financial management, e.g. make sure they are investment ready (e.g. governance, clear and transparent accounting and financial systems, a compelling business planning, legal, tax compliance etc.).

3. Promote scenarios, business models, opportunities and tools for financial services and products, guarantee systems and tailored auditing mechanisms; engage in human capacity development on seed systems with banks and financial institutions.

4. Engage in advocacy among multilateral financial institutions, banks and the government to consider opportunities in the sector.

5. Promote partnerships between financial institutions, commercial banks and seed sector stakeholders for piloting and scaling seed financing services and products.

Stakeholders - Seed companies and seed producers

- Commercial bank(s) with a profile in the agricultural sector

- Auditing company with a profile in the agricultural sector

- FMARD/Agribusiness Department; FMoF; CBN

- International development partners and funders

- International financial institutions, e.g. International Finance Corporation (IFC)/World Bank, Islamic Corporation for the Development of the Private Sector (ICD)/IsDB.

Catalyst Consulting firm with knowledge of both the seed and financial sectors that works closely with concerned stakeholders, including the Central Bank of Nigeria and/or the Ministry of Foreign Affairs in partnership with local financial service providers in the landscape. 


\begin{tabular}{|c|c|}
\hline $\begin{array}{l}\text { Policy } \\
\text { reference }\end{array}$ & $\begin{array}{l}\text { The APP (2016-2020) aims to enhance availability of multi-year finance as well as seasonal shorter-term } \\
\text { finance for agribusiness (which includes seed business) and agro-dealers. In order to achieve this, the } \\
\text { APP aims to enhance FMARD capacity in relation to agricultural finance. }\end{array}$ \\
\hline $\begin{array}{l}\text { Proposed five- } \\
\text { year horizon }\end{array}$ & $\begin{array}{l}\text { At least three commercial banks have an active portfolio of financial products and services, with specific } \\
\text { differentiation for seed business in crops such as maize, grain crops, RTBs and vegetables; they have at } \\
\text { least } 20 \text { seed companies and more than } 1,000 \text { seed producers in at least } 10 \text { states as clients, each of } \\
\text { whom uses at least two different products or services. }\end{array}$ \\
\hline $\begin{array}{l}\text { Illustrative } \\
\text { examples }\end{array}$ & $\begin{array}{l}\text { ISSD Africa ( } 2017 \text { ) has conducted a study to identify and characterize finance for seed business. It } \\
\text { provides the following examples: Cinzana Seed Producer Cooperative in Mali has been able to access } \\
\text { credit from BNDA, guaranteed by the AfDB; CORIS Bank has been providing seed producers in Burkina } \\
\text { Faso with access to credit as part of rice value chain integration; and seed warehouse receipt system } \\
\text { financing in Malawi has been addressing inherent cash flow challenges in seed business. }\end{array}$ \\
\hline
\end{tabular}

\title{
4.7 Coordination \& governance
}

\section{Sector governance \& coordination (SIP-CG1)}

\begin{abstract}
Ambitions Enhanced governance of the seed sector with institutional responsibilities for governance and regulation; a structured and functional National Seed Sector Platform; a collaborative and sector-driven implementation of the NSRM; and improved coordination between public and private stakeholders in seed sector development (coordination \& governance).

Challenge The seed sector is complex with different seed systems and seed value chains and involving a wide range of stakeholders. In its performance, the sector is characterized by limited alignment of stakeholders in their actions and overlapping interventions. The sector is deficient in accountability and has a limited capacity to monitor progress in its development and engage in joint decision-making to tackle its constraints. The promotional and marketing activities of the sector that drive the demand for quality seed of improved varieties is limited. The NASC lacks a structured partnership and associated process, which has created a gap in the sector's management of stakeholder relations and partnerships. The NASC manages Seed Connect, which provides a platform function. However, the Alliance for Seed Industry in West Africa (ASIWA) established a platform that is not functional. Consequently, the sector is characterized as inefficient and ineffective in delivering quality seed of new and improved varieties to farmers. Improved coordination is required to enhance sector governance, but also to increase alignment and communication among research organizations, seed companies and producers, agro-dealer networks, service providers and regulators.
\end{abstract}

Strategic 1. Support and enhance the human capacity of the NASC at systems level, e.g. in taking up its innovation coordinating role, according to its new five-year institutional strategic plan (2020-2024), including pathway platform secretariat functions.

2. Establish a National Seed Sector Platform (or re-adjourn and transform previously established platforms) that brings together key seed sector stakeholders from government, civil society, knowledge institutes and industry; facilitate dialogue; clarify and consolidate roles and responsibilities; support collaboration; foster development and use of a digital information portal; enhance systems and value chain oriented human capacity required for such coordination and platform management; leverage the platform to introduce the Nigerian Seed Week which will include regional seed week seminars and the national Seed Connect Conference organized by the NASC; establish communication channels with industry stakeholders leveraging the NASC website and social media platforms; and convey seed industry insights, newsletters and annual reports of seed sector stakeholders including the NASC and SEEDAN.

3. Based on the NSRM and using a consultative process, develop detailed action plans with budgets on priority topics.

4. In accordance with NASC law and its strategic plan, support the National Seed Sector Platform to consolidate the capacities of institutions in governing the seed sector; provide inputs review amendments to seed policies and legislation; review and monitor their implementation; support the platform to provide inputs but not engage in decision-making.

5. Share new developments and successful innovations and explore their scaling.

Stakeholders - FMARD; NASC and NAQS

- SEEDAN, seed companies and other seed entrepreneurs

- NARIs, universities and CGIAR Centers 
- NGOs working in the seed sector; farmer organizations.

\begin{tabular}{|c|c|}
\hline Catalyst & $\begin{array}{l}\text { Consulting firm or NGO with experience in guiding multi-stakeholder partnerships for seed sector } \\
\text { transformation in close collaboration with the NASC and SEEDAN. }\end{array}$ \\
\hline $\begin{array}{l}\text { Policy } \\
\text { reference }\end{array}$ & $\begin{array}{l}\text { The APP (2016-2020) highlights the lack of communication and coordination in the sector. The NASC } \\
\text { strategic plan (2020-2024) provides guidance for the NASC in taking its strategic role in the governance } \\
\text { and regulation of the seed sector of Nigeria. }\end{array}$ \\
\hline $\begin{array}{l}\text { Proposed two- } \\
\text { year horizon }\end{array}$ & $\begin{array}{l}\text { The National Seed Sector Platform has been established with a clear structure in which relevant } \\
\text { stakeholders participate. Activities linked to the implementation of the NSRM and other developments are } \\
\text { discussed, elaborated and monitored, contributing to seed sector transformation. }\end{array}$ \\
\hline $\begin{array}{l}\text { Proposed five- } \\
\text { year horizon }\end{array}$ & $\begin{array}{l}\text { The National Seed Sector Platform is operational; it owns the NSRM, reviews achievements, manages } \\
\text { updates and develops new plans. The platform ensures alignment of stakeholders in their actions, reduces } \\
\text { overlap of interventions, and increases efficiency and accountability. It contributes to sector governance, } \\
\text { reviews and monitors management and implementation of regulations, while also providing inputs to } \\
\text { required improvements and decision-making processes. The National Seed Sector Platform is sustainable } \\
\text { in its governance and in funding its coordination and other activities. }\end{array}$ \\
\hline $\begin{array}{l}\text { Illustrative } \\
\text { examples }\end{array}$ & $\begin{array}{l}\text { - The regional seed sector core groups, as established and supported by ISSD Ethiopia, played a critical } \\
\text { role for dialogue and contributed to addressing institutional seed sector challenges, e.g. liberalizing } \\
\text { seed marketing, ensuring EGS supply, and promoting innovations in seed quality assurance systems; } \\
\text { regionally based universities and a state-run seed company operated as catalyst (WUR, 2020c). } \\
\text { - The National Seed Plan for Ghana provides an example of action planning with clear objectives and } \\
\text { coordination in activities, envisaged results, budgets and role divisions for strategic areas in the } \\
\text { development of the seed sector in Ghana (MOFA, 2015). } \\
\text { - The Myanmar Seed Portal provides online seed information to stakeholders and supports its national } \\
\text { seed platform (MOALI, 2020). }\end{array}$ \\
\hline
\end{tabular}

\section{Seed information (SIP-CG2)}

Ambitions Increased availability and reliability of information on seed and seed business for all stakeholders (coordination and governance); enhanced access to and use by stakeholders of accurate industry and market information, which supports proper production planning (production systems), marketing and promotion of new varieties (market development), EGS forecasting and supply, seed quality assurance and financial services tailored to the seed sector (service provision); increased efficiency and effectiveness of the sector through the use of modern systems for seed information management and sharing (IMS) (revenue generation \& reinvestment).

Challenge The seed sector is constrained in its performance by a limited capacity to collect, manage and share data and other information on seed sector-related subjects such as logistics, manpower, resources and technology. If information is collected and standards are available, they only target major cereals and commercial and formal seed systems. The information available does not cover RTBs, legumes, small grains and vegetables, nor is it applicable to intermediary (CBSP and local entrepreneurs) and informal seed systems. Extension services, agro-dealers and farmers have difficulties in finding information on sources of seed and new varieties. They cannot easily access information, e.g. in a variety catalogue, on variety recommendations per location and agro-ecology, their product profiles and market attractiveness. Moreover, if available, information is often unreliable. This situation impacts, for example, on the effectiveness and efficiency in EGS production, forecasting and supply, as well as on seed quality assurance, production and marketing of quality seed, and access to finance.

Strategic

innovation pathway
1. Assess the current status and capacity among key stakeholders in data collection, information management and sharing (IMS); identify critical demands for specific types of information (e.g. seed availability and demand; EGS availability and demand; financial information); assess available and existing seed IMS systems.

2. Explore ways for strengthening IMS capacities (including human and technical capacity); design and setup collaborative IMS clusters (e.g. groups of organizations that collaborate in IMS for a specific crop or topic linked with the NASC's seed databank); develop seed demand forecasting systems within crop specific IMS clusters involving all stakeholders; conduct biennial national seed surveys to gather data on key trends in the seed sector, including seed demand and supply dynamics; develop one-stop service portals for the IMS clusters; develop ecosystems and business models for service provision within the IMS clusters, ensuring financial sustainability.

3. Enhance the human (technology and systems focused), technical and operational capacity among critical stakeholders (e.g. the NASC and SEEDAN) in information collection, record keeping, management and sharing; support the setup of IMS clusters.

4. Promote and advance the use of technology in IMS among stakeholders. 
5. Ensure that crops such as legumes, small grains, RTBs and vegetables have standards and are included in the IMS clusters.

Stakeholders - FMARD, NASC, NACGRAB, research organizations, universities and CGIAR Centers, National Bureau of Statistics (NBS)

- SEEDAN, seed companies and producers, NGOs, farmer organizations

- ICT companies.

Catalyst Consulting firm with IMS expertise in partnership with the NASC, SEEDAN and a knowledge organization operating in the agricultural and seed sector.

Policy The APP (2016-2020) indicated that information collection and evidence-based reporting in the reference agricultural sector is weak. The NASC strategic plan (2020-2024) aims to leverage technology and ensure financial sustainability of the seed databank and associated one-stop-shop for sharing seed information.

Proposed two- NASC's seed databank and IMS clusters are operational, they contain evidence-based information or year horizon reliable data/information; stakeholders in two regions of the country have started to access information through dedicated portals; IMS clusters pilot ways to share information with stakeholders on a partial cost-recovery basis; seed stakeholders have formed IMS clusters through which they work together in IMS and which are not fully subsidized.

Proposed five- At a national scale, stakeholders in the seed sector, e.g. seed companies and producers, research year horizon organizations, extension agents and farmers, but also policy makers, access and use information within the NASC's seed databank and the established IMS clusters. This information is evidence-based and reliable; they cover a wide diversity of crops and seed systems; the seed databank and IMS clusters have dedicated resources and users pay for accessing information; a significant share of budgets of the seed databank and IMS clusters is generated through cost-based information sharing.

Illustrative - AVISA shares information on breeding programmes and seed systems for legumes and small grains examples with research organizations, seed companies and producers; its aim is to enable the private sector to seize opportunities on the commercialization of these crops (ICRISAT, 2020a).

- In Myanmar, a seed demand forecasting system has been developed (MOALI, 2020); it recently gained recognition at the Asia Smart App Awards.

\section{Seed trade association (SIP-CG3)}

Ambition Enhanced structure, functioning and governance of SEEDAN, ensuring coverage and representation of all agricultural zones, crops and business types (coordination \& governance).

Challenge National seed trade associations serve as coordinating bodies for domestic seed entrepreneurs, but also as entry points into the market for foreign seed companies. SEEDAN, the Seed Entrepreneurs Association of Nigeria, aims to: (i) serve as a seed industry forum for promoting sector growth by discussing common interests; (ii) develop operational ethics and guidelines; (iii) support policy formulation; and (iv) serve the seed industry as a reference and speaking point for communications with authorities, institutions, projects and NGOs. 314 seed companies and more than 140 producers are registered with the NASC; 72 seed companies are SEEDAN members. The association has a basic structure, but it has neither regional divisions, nor subgroups organized according to either commodities or different types of seed businesses (such as international and domestic seed companies, seed producers, associations of farmer seed producers, seed traders, agro-dealers). This structure results in a limited representation and capacity to address the demands of a diversity of seed entrepreneurs operating in the country, thereby restricting its legitimacy as a private sector representative. Current members mainly produce, trade and market seed of cereal and legume grain crops of largely public varieties, with limited interest in RTBs and vegetables. In order to become professional, SEEDAN should strengthen its representation to the outside world, enhance its governance and structure, and begin to provide services to its members. These are preconditions for attracting new paying members, strengthening its leadership position in promoting seed industry development, and also enforcing its institutional and financial sustainability.

Strategic 1. Conduct a survey among a wide diversity of local, domestic and global seed entrepreneurs, including innovation existing and potential members of SEEDAN, to explore needs and interests in relation to its structure pathway and services.

2. Assess SEEDAN's current organizational structure and governance, identify its institutional strengths and weaknesses, and opportunities in relation to providing services to its members.

3. Support the development of a five-year strategy and two-year workplan to facilitate the further refinement of SEEDAN's organizational structure and governance, in relation to needs of different types of members and those in different regions of the country.

4. Support the development and implementation of modalities, including piloting specific services, facilitating general and specific subchapter activities in which members can meet each other, align needs and opportunities, and work together on topics of interest. 
5. Develop and implement activities for human and operational capacity strengthening of SEEDAN, as well as capacity development programmes targeting its members.

\begin{tabular}{|c|c|}
\hline ake & $\begin{array}{l}\text { - SEEDAN } \\
\text { - Seed entrepreneurs, including local, domestic and international seed companies, seed producers, other } \\
\text { seed entrepreneurs and agro-dealers. }\end{array}$ \\
\hline atalyst & $\begin{array}{l}\text { NGO or consulting firm with knowledge and expertise in supporting the development of national seed } \\
\text { trade associations or other professional membership-based organizations, in partnership with the NASC, } \\
\text { and a regional or other national seed trade associations. }\end{array}$ \\
\hline $\begin{array}{l}\text { Policy } \\
\text { reference }\end{array}$ & $\begin{array}{l}\text { The APP (2016-2020) aims to attract investors in the agricultural sector by supporting the development of } \\
\text { a conducive business environment. The NASC's strategic plan (2020-2024), identifies the NASC as the } \\
\text { key public convenor of the seed sector and mentions the importance of SEEDAN's support in the } \\
\text { development of the seed sector. }\end{array}$ \\
\hline $\begin{array}{l}\text { roposed five- } \\
\text { ear horizon }\end{array}$ & $\begin{array}{l}\text { Revised organizational structure with subchapters at geography, crop and/or type of business; two new } \\
\text { services operational for members; } 100 \text { members, which include } 5 \text { international seed companies and at } \\
\text { least } 20 \text { local seed entrepreneurs and/or seed traders; active participation in the African Seed Trade } \\
\text { Association (AFSTA) and possibly the International Seed Federation (ISF); involvement in the regional } \\
\text { efforts to harmonize seed movement. }\end{array}$ \\
\hline $\begin{array}{l}\text { Proposed ten- } \\
\text { year horizon }\end{array}$ & $\begin{array}{l}\text { SEEDAN recognized within Nigeria and beyond as a well-functioning seed trade association, with } 90 \% \text { of } \\
\text { the seed entrepreneurs operating in Nigeria registered as members. }\end{array}$ \\
\hline $\begin{array}{l}\text { Illustrative } \\
\text { examples }\end{array}$ & $\begin{array}{l}\text { - SANSOR (2020) is a well-developed, internationally recognized and financially viable seed trade } \\
\text { association providing a wide package of services its members. } \\
\text { - The Seed Trade Association of Kenya (STAK, 2020) has gone through a process of institutional reform } \\
\text { and strengthening over the past five years; it has become financially viable, and is active in advocacy, } \\
\text { capacity building, comprehensive information sharing, and seed trade promotion. }\end{array}$ \\
\hline
\end{tabular}

Alignment of donor interventions (SIP-CG4)

Ambition Increased coordination and alignment among donor and development organizations in the seed sector (coordination \& governance).

Challenge Donor and development organizations intervene both directly and indirectly in the seed sector. Direct efforts target systemic aspects of seed sector development; indirect efforts address particularly the demand, production, marketing and dissemination of quality seed for strengthening specific crop value chains in focus states, and/or support the development of agribusiness and private sectors. The Bill \& Melinda Gates Foundation (BMGF) is supporting variety development for several crops through IITA, ICRISAT and other CGIAR Research Centers; these programmes often include a seed component. AGRA, with the support of USAID, is addressing EGS supply and is tackling the issue of counterfeit seed in the seed sector; it supports the introduction of plant variety protection (PVP). The Coalition for African Rice Development (CARD) with the support of JICA, is strengthening EGS and quality seed supply for improved rice varieties. The Netherlands is creating awareness and building capacity for PVP, as well as supporting the promotion of improved vegetable varieties. Private sector development projects (World Bank, USAID and $\mathrm{GiZ}$ ) and value chain development projects (IFAD, World Bank, IsDB and GiZ) create a seed demand and support seed provision; in some cases, they support the production and marketing of quality seed of their target crops. Humanitarian and food security programmes operating especially in the north-eastern region of Nigeria disseminate seed of food security crops. Given agricultural development is high on the agenda of several development partners, they meet regularly in the Agricultural Development Donor Working Group (ADWG), which advises FMARD on agricultural issues. FMARD and donors recognize the group as of formal character. The interactions address high-level aspects, and respective projects and interventions; they do not address in-depth sectorial aspects required for coordination and alignment of their interventions, such as in the seed sector. Coordination and alignment among development partners would enhance the effectiveness, relevance and impact of the individual and collective efforts on the development of the seed sector, while also reducing the potential overlap or duplication of interventions.

Strategic innovation pathway
1. Assess and map donor activities directly and indirectly impacting the seed sector within the framework of the NSRM.

2. Engage with the ADWG group to develop and operationalize a mechanism for coordination and alignment among development partners on seed sector issues, and to contribute to the NSRM; collaborate with FMARD, state ministries of agriculture and other relevant seed sector stakeholders in this effort.

3. Regularly monitor and document the impact of both individual and accumulated interventions contributing to NSRM implementation; share impact and lessons learned with the ADWG and primary 
seed sector stakeholders; and provide inputs for a continued alignment and scoping of modalities to

achieve other ambitions.

\begin{tabular}{|c|c|}
\hline takeholders & $\begin{array}{l}\text { - Development partners and donors in the ADWG } \\
\text { - FMARD; state ministries of agriculture } \\
\text { - Seed sector stakeholders (e.g. the NASC, SEEDAN, research organizations and CGIAR Centers). }\end{array}$ \\
\hline Catalyst & $\begin{array}{l}\text { Consulting firm or knowledge organization that provides supports as an executive secretariat to the } \\
\text { ADWG; the catalyst is overseen in this function preferably by two ADWG members with a strong profile in } \\
\text { the seed sector. }\end{array}$ \\
\hline $\begin{array}{l}\text { Policy } \\
\text { reference }\end{array}$ & No references. \\
\hline $\begin{array}{l}\text { Proposed two- } \\
\text { year horizon }\end{array}$ & $\begin{array}{l}\text { Specific sessions of the ADWG address seed sector development in which the group seeks alignment and } \\
\text { coordination of their interventions with the aim to contribute to the development of the seed sector. }\end{array}$ \\
\hline $\begin{array}{l}\text { Illustrative } \\
\text { examples }\end{array}$ & $\begin{array}{l}\text { In Myanmar, } 60 \text { key representatives of the public sector, private sector, and development partners, } \\
\text { including donors, meet twice per year in a platform meeting to discuss key seed sector issues, and allow } \\
\text { for discussions on collaboration and alignment of seed sector interventions (WUR, 2020a). }\end{array}$ \\
\hline
\end{tabular}

\subsection{Regulation \& management}

\section{Plant variety protection (SIP-RM1)}

\begin{tabular}{|c|c|}
\hline Ambitions & $\begin{array}{l}\text { Adopted Plant Variety Protection Bill; operational UPOV-PVP system that supports the development of the } \\
\text { seed sector (regulation \& management; revenue generation \& reinvestment). }\end{array}$ \\
\hline Challenge & $\begin{array}{l}\text { Plant variety protection (PVP) gives breeders intellectual property rights over a new plant variety, with } \\
\text { exclusive rights to commercialize seed and/or propagation material of the variety. PVP promotes the } \\
\text { marketing of new varieties and allows breeders to earn back the considerable costs involved in the long } \\
\text { process of variety development. A well-functioning PVP system encourages in-country breeding activities; } \\
\text { it also attracts foreign companies to introduce high-quality improved varieties, knowing that others } \\
\text { cannot easily reproduce and take advantage of their investments in variety development. Nigeria is in the } \\
\text { process of passing the PVP Bill. Once passed, the country has to put considerable effort in the } \\
\text { development and operationalization of a functional PVP system and work on an appropriate enforcement } \\
\text { system. The NASC, breeders and seed companies give high priority to its operationalization. Sector-wide } \\
\text { understanding and ownership is crucial for PVP to result in the availability of better varieties for farmers. }\end{array}$ \\
\hline & $\begin{array}{l}\text { 3. Support the implementation of the PVP system, including the establishment of a PVP office and } \\
\text { facilities for testing for distinctiveness, uniformity and stability (DUS); engage in human and } \\
\text { operational capacity development of staff of involved organizations. }\end{array}$ \\
\hline & $\begin{array}{l}\text { 4. Create awareness and ensure ownership in PVP with seed sector stakeholders at all levels; address } \\
\text { relevant issues such as the benefits of PVP, and the link between PVP, the seed law and variety } \\
\text { release modalities. }\end{array}$ \\
\hline & 5. Create a specialized court on infringements of breeders' rights with specialized lawyers. \\
\hline Stakeholders & $\begin{array}{l}\text { - NASC; research organizations for DUS testing } \\
\text { - FMARD; Ministry of Justice; Ministry of Trade; National Assembly } \\
\text { - Research/breeders, both public and private } \\
\text { - Seed producers, both public and private } \\
\text { - NGOs } \\
\text { - Farmers } \\
\text { - UPOV. }\end{array}$ \\
\hline Catalyst & $\begin{array}{l}\text { The NASC, with support from international organizations experienced in guiding the development and } \\
\text { operationalization of a functional PVP system. }\end{array}$ \\
\hline $\begin{array}{l}\text { Policy } \\
\text { reference }\end{array}$ & $\begin{array}{l}\text { Reference documents are the Plant Variety Protection Bill, 2019; and the National Agricultural Seeds } \\
\text { Council Act, } 2019 \text { (Part VIII, section 39). }\end{array}$ \\
\hline $\begin{array}{l}\text { Proposed five- } \\
\text { year horizon }\end{array}$ & $\begin{array}{l}\text { PVP Bill passed; PVP regulations approved; PVP office and DUS testing facilities established and } \\
\text { operational; an increased number of varieties registered and protected by Plant Breeders' Rights. }\end{array}$ \\
\hline $\begin{array}{l}\text { Proposed ten- } \\
\text { year horizon }\end{array}$ & $\begin{array}{l}\text { Fully functional PVP system; a significant number of new varieties registered and protected by plant } \\
\text { breeders' rights on a yearly basis; significantly increased entry of new plant varieties into the country; }\end{array}$ \\
\hline
\end{tabular}


both public and private domestic breeders protect their varieties; both public organizations and

companies gain financial resources for their investments in variety development.

Illustrative - Since implementing PVP, Kenya has seen a very positive impact especially on investment in the cutexamples flower industry (Kimani, 2018).

- Vietnam has developed its PVP system (2000-2006) and became a member of UPOV in 2006; PVP has contributed tremendously to the development of the seed industry; an increased number of improved varieties of both food and commercial crops have become available for farmers (Minh, 2019).

- Naktuinbouw (Netherlands) has developed a PVP Toolbox, which is used to raise awareness and support the operationalization of PVP in Nigeria and other countries; Naktuinbouw has been engaging with a high-level delegation from Nigeria to explore and guide future steps for PVP implementation in Nigeria.

\section{Variety release (SIP-RM2)}

Ambitions Increased efficiency and transparency in variety release procedures with a more realistic cost-benefit ratio (regulation \& management; service provision; revenue generation \& reinvestment); enforced ECOWAS harmonization on variety release that supports private sector investment (regulation \& management).

Challenge To ensure that only high-performing and well-adapted varieties enter the seed market, a newly developed variety needs to be officially registered and released. This process involves mandatory on-station testing for DUS, multi-location trials for testing their value for cultivation and use (VCU), and multi-location onfarm trials. Based on the results, the National Crop Varieties Livestock Breeds Registration and Release Committee (NCVLBRRC) approves or rejects registration and release of the new variety. The committee should meet twice a year, but due to budgetary constraints and limited applications, it meets just once a year. On average, the process takes 43 months, with costs of the variety trials between US $\$ 2,000$ and US $\$ 27,000$ (TASAI, 2019). Nigeria does not yet enforce the seed policy provisions of ECOWAS on variety release, which, for example, exempt specific vegetables from trials for testing for value for cultivation and use (VCU). Since the numbers of new varieties as well as turnover of varieties for crops like vegetables are high, foreign companies find the required efforts for variety release to exceed the benefits. They limit the applications for variety release, which results in farmers' limited access to better and market demanded varieties.

Strategic 1. Assess the efficiency, transparency and cost-effectiveness of the current system of variety innovation registration and release as compared to other countries and to ECOWAS seed regulations; elaborate pathway and propose a strategy for strengthening and/or simplifying the variety release system, considering an exemption for specific crops (vegetables) and support for third-party variety testing.

2. Support enforcement of the ECOWAS seed regulations; support access to regional markets for Nigerian companies and encourage introduction of new varieties of international companies into Nigeria.

3. Strengthen the infrastructural and human resource capacities of NARIs with crop mandates for variety trial implementation.

4. Ensure easy access to an updated national variety catalogue which also allows farmers to select varieties matching their agro-ecology, farming systems and market demands (through the seed tracker).

5. With the PVP system in place, develop a system in which VCU and DUS testing is combined in one application for both variety release and PVP.

Stakeholders - NCVLBRRC, NACGRAB, NASC

- NARIs with mandates for specific crops.

Catalyst Organization/consultancy firm with experience in the assessment and reform of seed regulations and in the facilitation of institutional development.

Policy The NASC strategic plan (2020-2024) highlights the NASC's task of promoting variety registration and reference release. The NASC Act (2019) indicates that the NCVLBRRC sets the general rules for variety registration and release, which are further elaborated in the guidelines for registration and release of new crop varieties in Nigeria. NACGRAB publishes the crop variety catalogue (NACGRAB, 2020).

Proposed two- Based on an assessment, the opportunities for modernizing and simplifying the variety release system are year horizon acknowledged among policy makers and stakeholders involved, and a strategy for such a reform is approved; insights into the benefits of enforcing ECOWAS regulations are available and shared; a decision on its enforcement is made.

Proposed five- The procedures and structure for variety release are fast, affordable and transparent; global and domestic year horizon companies no longer consider variety release an obstacle for the introduction of new varieties into the country. Research organizations have the capacity to conduct the required trials in a cost-effective and transparent manner. 


\section{Seed import (SIP-RM3)}

\begin{tabular}{|c|c|}
\hline Ambition & $\begin{array}{l}\text { Increased efficiency, predictability and transparency of seed import procedures and conditions at ports } \\
\text { and borders, supported by a one-stop digital portal, that enables seed business development (regulation } \\
\text { \& management; service provision); zero-import tariffs applied to seed of selected crops, similar to other } \\
\text { agricultural inputs (revenue generation \& reinvestment). }\end{array}$ \\
\hline Challenge & $\begin{array}{l}\text { Due to the weak alignment in procedures of the NASC, NAQS and Nigeria Customs Services, seed } \\
\text { importation is inefficient. Consequently, the import of quality seed of maize hybrids and vegetables by } \\
\text { both domestic and international seed companies in Nigeria is difficult. Because of its bulky nature and } \\
\text { fragility, seed potato imports are even more affected. Corruption at ports and borders further aggravates } \\
\text { this situation. The outcome is that seed companies that depend on the importation of seed and planting } \\
\text { materials, such as those active in vegetable seed and seed potatoes, are constrained in their business. } \\
\text { This challenge creates a barrier for foreign seed companies to start bringing their seed and varieties to } \\
\text { the Nigerian market; it also jeopardizes domestic companies depending on importation (e.g. vegetables). } \\
\text { Another challenge is that the zero-import tariffs for agricultural inputs similar to fertilizer and crop } \\
\text { protection products are not applicable to seed. This further impacts on business, the seed price and thus } \\
\text { seed affordability for and use by farmers. }\end{array}$ \\
\hline \multirow[t]{2}{*}{$\begin{array}{l}\text { Strategic } \\
\text { innovation } \\
\text { pathway }\end{array}$} & $\begin{array}{l}\text { 1. Assess the impact of the current constraints for seed imports (lack of alignment among agencies, } \\
\text { corruption and absence of zero-import tariffs) on the development of the seed industry, crop value } \\
\text { chains and farmers, particularly relevant to the importation of quality seed of maize hybrids, } \\
\text { vegetables and potatoes; assess and compare differences in prices for imported seed in Nigeria with } \\
\text { comparable countries in West Africa. }\end{array}$ \\
\hline & $\begin{array}{l}\text { 2. Identify opportunities to address the constraints through ensuring better coordination among public } \\
\text { bodies; through intervention from FMARD and FMoF, establish a strong inter-agency collaboration } \\
\text { between NASC, NAQS and Nigeria Customs, to harmonize the seed import policy, and enhance } \\
\text { efficiency, predictability and transparency. }\end{array}$ \\
\hline Stakeholders & $\begin{array}{l}\text { - FMARD, FMoF, Nigeria Customs Services, NASC, NAQS } \\
\text { - ICT company (portal development) } \\
\text { - SEEDAN } \\
\text { - Domestic and international seed companies } \\
\text { - International regulatory and standards organizations. }\end{array}$ \\
\hline Catalyst & Consulting firm with a profile in the seed sector, regulations and IT solutions. \\
\hline $\begin{array}{l}\text { Policy } \\
\text { reference }\end{array}$ & $\begin{array}{l}\text { The NASC strategy ( } 2020-2024) \text { outlines that the NASC engages with FMARD to facilitate a cordial inter- } \\
\text { agency collaboration between the NASC and NAQS on seed import; it aims to digitalize and increase } \\
\text { efficiency and accountability of importation procedures. The NASC Act (2019) regulates the import of } \\
\text { seed; it refers to variety registration and release, and seed quality aspects. }\end{array}$ \\
\hline $\begin{array}{l}\text { Proposed five- } \\
\text { year horizon }\end{array}$ & $\begin{array}{l}\text { The one-window seed import portal is operational, companies use it and transaction costs are reduced; } \\
\text { efficiency and accountability of seed import at ports and borders has increased. Combined with zero tariffs } \\
\text { on seed, this results in a significant increase in imported seed of improved varieties of a wide portfolio of } \\
\text { crops, including hybrid maize, vegetables and potato, thereby fostering the development of these value } \\
\text { chains. }\end{array}$ \\
\hline $\begin{array}{l}\text { Illustrative } \\
\text { examples }\end{array}$ & $\begin{array}{l}\text { - The Indian government has launched a specific seed import and export portal (GOI, 2020). } \\
\text { - The Government of Myanmar (MOALI, 2020) has recently launched a seed portal bringing together all } \\
\text { information relating to seed sector regulation, including options for on-line application for seed business } \\
\text { related permits; a digital seed platform includes a one-stop-shop that can be used by seed companies } \\
\text { for electronic applications for all seed regulatory services (including variety registration, business } \\
\text { licensing and seed import). }\end{array}$ \\
\hline
\end{tabular}


- The ABCs of Seed Importation into Canada is an example of a seed portal that provides importers with an overview of the import process, information on importation documents, answers to frequently asked questions along with information regarding other legislation that may also apply (CFIA, 2020).

\section{Seed export (SIP-RM4)}

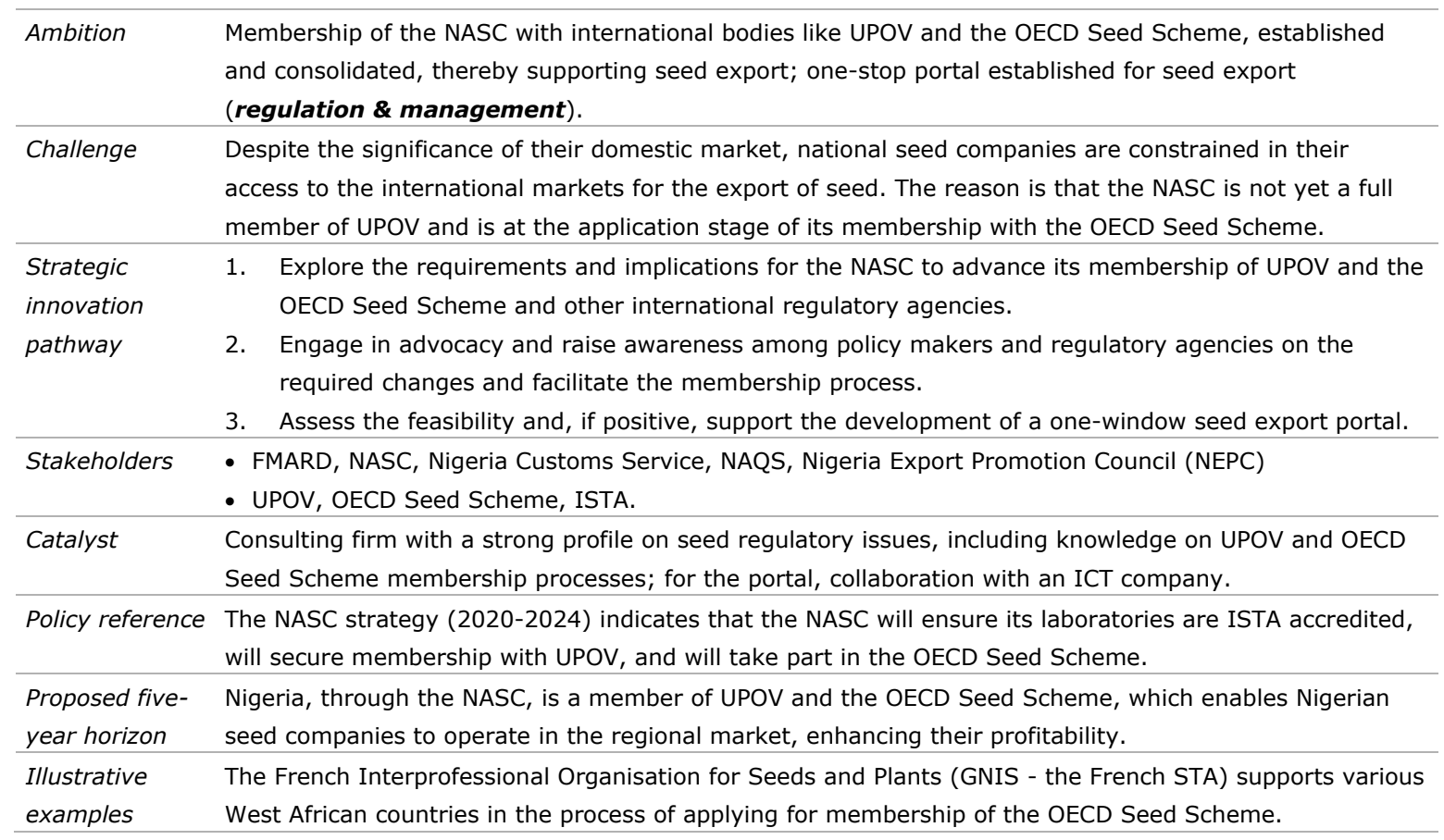




\section{References and links}

AGRA, 2017. Seeding an African green revolution: the PASS journey. AGRA, Nairobi.

(https://agra.org/wp-content/uploads/2018/02/PASS-Book-web.pdf)

AgroNigeria, 2019. NASC to activate SeedCodex tracking app to check adulterated seeds.

(https://agronigeria.ng/2019/11/12/nasc-to-activate-seedcodex-tracking-app-to-check-

adulterated-seeds/)

Aidenvironment, IIED, Sustainable Food Lab, 2017. An Overview of Sector Governance: Looking beyond the value chain to build high performing and resilient agriculture sectors. Aidenvironment, Amsterdam. (http://www. aidenvironment.org/wp-content/uploads/2017/12/Sector-GovernanceShort-Paper-Dec2017.pdf)

Ashour, M., Billings, L., Gilligan, D.O., Karachiwalla, M., 2015. Evaluation of the impact of everification on counterfeit agricultural inputs and technology adoption in Uganda. Baseline Report. International Food Policy Research Institute, Washington D.C.

(http://ebrary.ifpri.org/utils/getfile/collection/p15738coll2/id/129247/filename/129458.pdf)

AtSI, 2019. Access to Seeds Index: Western and Central Africa report. Access to Seeds Index, Amsterdam. (https://www.accesstoseeds.org/index/western-central-africa/)

BMGF \& USAID, 2015. Early Generation Seed Study. BMGF, Seattle \& USAID, Washington, DC. (https://docs.gatesfoundation.org/documents/BMGF\%20and\%20USAID\%20EGS\%20Study\%20Ful 1\%20Deck.pdf)

CBN, 2016. Anchor Borrowers' Programme Guidelines. Development Finance Department Central Bank of Nigeria, Abuja.

(https://www.cbn.gov.ng/out/2017/dfd/anchor\%20borrowers\%20programme\%20guidelines\%20dec\%20\%202016.pdf)

CFIA, 2020. ABCs of seed importation into Canada. Canadian Food Inspection Agency, Ottawa.

(https://inspection.gc.ca/plant-health/seeds/seed-imports/abcs-of-seed-

importation/eng/1347740952226/1347741389113)

CGIAR, 2020. CGIAR Excellence in breeding platform. CGIAR, Montpellier.

(https://www.cgiar.org/excellence-breeding-platform/)

Context Network \& Sahel Capital, 2016. Nigeria Early Generation Seed Study. Context Network, West Des Moines \& Sahel Capital, Lagos.

(https://www.agrilinks.org/sites/default/files/resource/files/Nigeria-EGS-Study-Final-Report-

August-2016.pdf)

East-West Seed, 2020. Training over 100,000 farmers in Africa by 2022. East-West Seed, Nonthaburi. (https://www.eastwestseed.com/news/training-over-100000-farmers-in-africa-by-2022)

EBA, 2017, Business of Agriculture report for Nigeria. World Bank, Washington, DC. (https://eba.worldbank.org/en/data/exploreeconomies/nigeria/2019)

EuropeanSeed, 2018. Boosting regional seed trade: How the East African Community is harmonizing seed regulations. European Seed. (https://european-seed.com/2018/11/boosting-regional-seedtrade-how-the-east-african-community-is-harmonizing-seed-regulations/)

FMARD, 2016. The Agriculture Promotion Policy (2016-2020); Building on the Successes of the ATA, Closing Key Gaps. Policy and Strategy Document. Federal Ministry of Agriculture and Rural Development, Abuja, FCT. (https://fscluster.org/sites/default/files/documents/2016-nigeria-agricsector-policy-roadmap_june-15-2016_final1.pdf)

FMARD, 2019. National Agricultural Seeds Council Act. Federal Ministry of Agriculture and Rural Development, Abuja, FCT. (https://seedcouncil.gov.ng/wp-content/uploads/2020/02/Seed-Act2019.pdf)

Global Yield Gap Atlas, 2020. Wageningen University Research, Wageningen \& University of Nebraska, Lincoln, NE. (http://www.yieldgap.org/)

GOI, 2020. Seed Export Import System. Government of India, Ministry of Agriculture and Farmers Welfare, Delhi. (https://seedexim.gov.in/)

ICRISAT, 2020a. AVISA Project. International Crops Research Institute for the Semi-Arid Tropics, Hyderabad. (https://www.avisaproject.org/) 
ICRISAT, 2020b. Tropical Legumes III: strategies for wider reach and deeper impacts. International Crops Research Institute for the Semi-Arid Tropics, Hyderabad. (https://www.icrisat.org/tropicallegumes-iii-strategies-for-wider-reach-and-deeper-impacts/)

IFAD, 2020. Integrated Value Chain Development Project. Project Profile. IFAD, Rome.

(https://www.ifad.org/en/web/operations/project/id/1100001594/country/nigeria)

IFPRI, 2020. International Food Policy Research Institute, Washington, DC. (http://www.ifpri.org/)

IITA, 2020a. Seed tracker. International Institute of Tropical Agriculture, Ibadan.

(https://seedtracker.org/\#)

IITA, 2020b. IITA GoSeed. (https://iitagoseed.com/)

IITA, 2020c. Yam Improvement for Incomes and Food Security in West Africa, Phase II (YIIFSWA II). International Institute of Tropical Agriculture, Ibadan. (https://www.iita.org/iita-project/yifswa-ii/)

ISSD Africa, 2017. Financing seed business. ISSD Africa Synthesis Paper. Wageningen University \& Research, Wageningen (http://www.issdseed.org/sites/default/files/case/issd_africa_twg1_sp3_seed_finance_170412.pdf)

Kariuki, J., 2017. Plant health agency ups fight against fake seeds. Business Daily. (https://www.businessdailyafrica.com/markets/news/Plant-health-agency-ups-fight-against-fakeseeds/3815534-4093312-ynp0ow/index.html)

KEPHIS, 2020. Kenya Plant Health Inspectorate Service, Nairobi. (https://www.kephis.org/)

Kimani, E., 2018. Benefits of Plant Variety Protection and UPOV Membership: The Case of Kenya. European Seed. (https://european-seed.com/2018/11/benefits-of-plant-variety-protection-andupov-membership-the-case-of-kenya/)

Minh, N.T., 2019. The tremendous impact of UPOV Membership in Vietnam. European Seed. (https://european-seed.com/2019/04/the-tremendous-impact-of-upov-membership-in-vietnam/)

MOALI, 2020. Myanmar Seed Portal. Ministry of Agriculture, Livestock and Irrigation, Naypyidaw. (http://myanmarseedportal.gov.mm/en)

MOFA, 2016. National Seed Plan. Plan for the implementation of the National Seed Policy. Ministry of Food and Agriculture, Accra. (https://tasai.org/wpcontent/themes/tasai2016/info_portal/Ghana/Ghana\%20National\%20Seed\%20Plan\%20(2015).pdf)

MSU, 2020. Department of Agricultural, Food and Resource Economics of Michigan State University, East Lansing, MI. (https://www.canr.msu.edu/afre/)

NACGRAB, 2020. Crop varieties released and registered in Nigeria. National Centre for Genetic Resources and Biotechnology, Ibadan. (https://nacgrab.gov.ng/images/Varieties_Released_Catalogue.pdf)

NASC, 2019. A Strategic Plan for the National Agricultural Seeds Council (NASC) 2020 to 2024. National Agricultural Seeds Council, Abuja, FCT. (https://seedcouncil.gov.ng/wpcontent/uploads/2020/02/Five-Year-Strategic-Plan-2020-2024.pdf)

QualiSeed, 2020. QualiSeed Company, Nairobi. (https://qualibasicseed.com/)

RTB-CGIAR, 2020a. Quality Seed Component. Building a Sustainable, Integrated Seed System for Cassava in Nigeria' (BASICS). RTB-CGIAR, Ibadan. (http://www.rtb.cgiar.org/sites/basics/activities/quality-seed/index.html)

RTB-CGIAR, 2020b. Building a Sustainable, Integrated Seed System for Cassava in Nigeria (BASICS). RTB-CGIAR, Ibadan. (http://www.rtb.cgiar.org/sites/basics/index.html)

RTB-CGIAR, 2020c. Village seed entrepreneurs. Building a Sustainable, Integrated Seed System for Cassava in Nigeria (BASICS). RTB-CGIAR, Ibadan. (http://www.rtb.cgiar.org/sites/basics/activities/village-seed-entrepreneurs/index.html)

SANSOR, 2020. South African National Seed Organization, Pretoria. (https://www.sansor.org/)

SEVIA, 2020. Seeds of Expertise for the Vegetable Sector of Africa. Sevia, Arusha. (https://www.sevia.biz/index.php/aboutsevia)

STAK, 2020. Seed Trade Association of Kenya, Nairobi. (http://www.stak.or.ke/)

Syngenta Foundation, 2019. Manual on regional seed regulations in the Common Market for Eastern and Southern Africa (COMESA). Syngenta Foundation, Basle. (https://www.syngentafoundation.org/sites/g/files/zhg576/f/manual_on_comesa_regional_seed_r egulations_final_19_february_2019.pdf)

TASAI, 2019. Nigeria Brief 2018, the African Seed Access Index. Nigeria Brief 2018 - The African Seed Access Index (https://tasai.org/wpcontent/themes/tasai2016/img/tasai_nigeria_brief_2018_Ir.pdf) 
UQ, 2020. Breeding Programme Assessment Tool (BPAT). University of Queensland, Brisbane.

(https://plantbreedingassessment.org/)

WUR, 2019a. Seed Sector Review Nigeria, Crop Briefs. Wageningen University \& Research, Wageningen (https://issdafrica.files.wordpress.com/2020/02/seed-sector-review-nigeria-cropbriefs_final.pdf)

WUR, 2019b. Seed Sector Review Nigeria, Assessment report. Wageningen University \& Research, Wageningen (https://issdafrica.files. wordpress.com/2020/02/seed-sector-review-nigeriaassessment-report_final.pdf)

WUR, 2019c. Seed Sector Review Nigeria. Multistakeholder Workshop Report. Wageningen University \& Research (https://doi.org/10.18174/515371)

WUR, 2020. Integrated Seed Sector Development. Wageningen University \& Research, Wageningen. (www.issdseed.org)

WUR, 2020a. Integrated Seed Sector Development in Myanmar. Wageningen University \& Research, Wageningen. (https://issdmyanmar.org/)

WUR, 2020b. Integrated Seed Sector Development in Uganda. Quality declared seed. Wageningen University \& Research, Wageningen.

(https://issduganda.org/programme/local_seed_businesses/quality_declared_seed/)

WUR, 2020c. Integrated Seed Sector Development in Ethiopia. Wageningen University \& Research, Wageningen (https://issdethiopia.org/)

WUR, 2020d. Integrated Seed Sector Development in Uganda. Wageningen University \& Research, Wageningen. (https://issduganda.org/)

WUR, 2020e. Integrated Seed Sector Development in Uganda. Uptake of quality seed. Wageningen University \& Research, Wageningen. (https://www.issduganda.org/programme/uptake_seed/) 
Wageningen Centre for Development Innovation

Wageningen University \& Research P.O. Box 88

$6700 \mathrm{AB}$ Wageningen

The Netherlands

$\mathrm{T}+31(0) 317486800$

www.wur.eu/cdi

Report WCDI-20-099
Wageningen Centre for Development Innovation supports value creation by strengthening capacities for sustainable development. As the international expertise and capacity building institute of Wageningen University \& Research we bring knowledge into action, with the aim to explore the potential of nature to improve the quality of life. With approximately 30 locations, 5,000 members of staff and 12,000 students, Wageningen University \& Research is a world leader in its domain. An integral way of working, and cooperation between the exact sciences and the technological and social disciplines are key to its approach. 



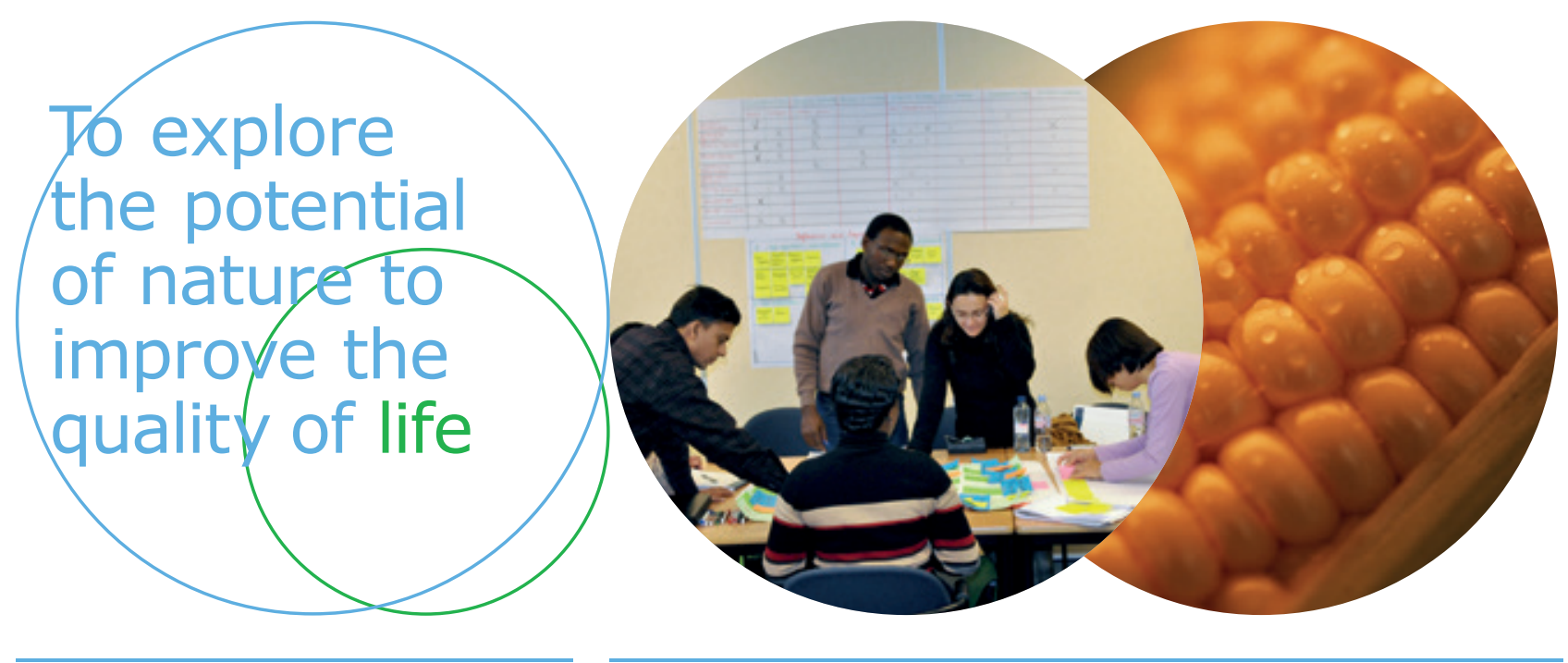

Wageningen Centre for Development Innovation Wageningen University \& Research P.O. Box 88 $6700 \mathrm{AB}$ Wageningen The Netherlands $\mathrm{T}+31$ (o)317 4868 oo www.wur.eu/cdi

Report WCDI-20-099
Wageningen Centre for Development Innovation supports value creation by strengthening capacities for sustainable development. As the international expertise and capacity building institute of Wageningen University \& Research we bring knowledge into action, with the aim to explore the potential of nature to improve the quality of life. With approximately 30 locations, 5,000 members of staff and 12,000 students, Wageningen University \& Research is a world leader in its domain. An integral way of working, and cooperation between the exact sciences and the technological and social disciplines are key to its approach. 